Araştırma Makalesi

\title{
Yeni Bir Pazarlama İletişimi Yaklaşımı Gerçek-Zamanlı Pazarlama: Otomobil Markalarının Geleceğe Dönüş Günü Sosyal Medya Pratikleri
}

\author{
Alper Yılmaz (Arş. Gör.) \\ İnönü Üniversitesi İletişim Fakültesi \\ alper.yilmaz@inonu.edu.tr
}

Başvuru Tarihi: 14.02.2018

Yayına Kabul Tarihi: 25.06.2018

Yayınlanma Tarihi: 30.07.2018

\section{Öz}

An. Zamanın en küçük birimi. Günlük hayat süresince yaşanılan her şey zamanın bu en küçük birimi olan "an"da çok hızlı bir şekilde gerçekleşmektedir. İnsanların "an"ı yaşadığı çağda markaların da "an"ı yakalamak için hedef kitlelerini iyi analiz etmeleri gerekmektedir. Günümüzde bireyler yeni medya araçlarını aktif bir şekilde kullanmaktadır. Dolayısıyla markaların hedef kitlelerini ve tüketicilerini dinlemeleri, gündemdeki güncel içeriklerle etkileşim oluşturacak içerikler üretmeleri, geleneksel pazarlama iletişimi planlarının dışına çıkarak farklılık oluşturmalarını ve anı yakalamalarını sağlamaktadır. An ve reklamın kesiştiği nokta pazarlama literatüründe "gerçek-zamanlı pazarlama/real-time marketing kavramıla ifade edilmektedir. Doyle (2005, 272) "gerçek-zamanlı pazarlama" kavramını reklam mesajlarının tüketicilere bir ya da daha fazla iletişim kanalından gerçek zamanlı olarak sunulması ve bu aktivitelerin etkililiğinin izlenmesi olarak tanımlamaktadır. Bilgi iletişim teknolojilerinin interneti geliştirmesi ve sosyal medya araçlarının hayatımızın merkezine yerleşmesiyle bir pazarlama iletişimi yaklaşımı olarak gerçekzamanlı pazarlama pratikleri günümüzde en çok dijital medyada gerçekleşmektedir.

$\mathrm{Bu}$ çalışma gerçek-zamanlı pazarlama/real-time marketing ve sosyal medyada kullanımını araştırmaktadır. Çalışma pazarlama iletişimi bağlamında otomobil markalarının "Geleceğe Dönüş Günü"/"Back to The Future Day" olarak adlandırılan 21 Ekim 2015 tarihi Çarşamba günü sosyal medyadaki gerçek-zamanlı pazarlama pratiklerini nitel araştırma yöntemi tasarımında örnek olay tarama modeli kullanarak gösterge bilimsel analiz tekniğiyle açıklamayı amaçlamaktadır.

Anahtar Kelimeler: Pazarlama İletişimi, Gerçek-zamanlı Pazarlama, Marka, Sosyal Medya, Otomobil. 
Research Article

\title{
A New Marketing Communication Approach Real-Time Marketing: Automobile Brand's Back to the Future Day Social Media Practices
}

\author{
Alper Yılmaz (Res. Asst.) \\ İnönü University Faculty of Communication \\ alper.yilmaz@inonu.edu.tr
}

Date Received: 14.02.2018

Date Accepted: 25.06.2018

Date Published: 30.07.2018

\section{Abstract}

Moment. The smallest unit at the time. Everything welive in everyday life happens very quickly in this smallest unit of time. When people are living "moments", brands need to analyze their target mass well in order to catch "moments". Individuals are actively using new media tools nowadays. Hence, brands creating new content, listening to existing and potential consumers, and creating content that will interact with upto-date content on the agenda, makes them different from traditional marketing communications schemes and capture the moment. Doyle $(2005,272)$ argues that the concept of "real-time marketing" means that advertising messages are presented in real time to consumers through one or more channels of communication, realtime marketing practices as a marketing communications approach is nowadays the most common in digital media, as information communication technology's internet development and social media tools are at the center of our lives.

This study explores the use of real-time marketing and social media. The aim of the study is to explain the real-time marketing practices in social media on the basis of the scientific analysis technique using the case study model in qualitative research method design on 21 October 2015 called "Back to the Future Day" of automobile brands in the context of marketing communication.

Keywords: Marketing Communication, Real-time Marketing, Brand, Social Media, Cars. 


\section{Giriş}

Real-Time Marketing/Gerçek-Zamanlı Pazarlama kavramı ilk olarak 1990’lı yıllarda bankacılık ve telekomünikasyon sektörlerindeki şirketlerin müşteri ilişkileri yönetiminde bir uygulama olarak ortaya çıkmıştır. Bilgi ve iletişim teknolojilerinin, internetin, yeni medyanın ortaya çıkışı ve yeni medyanın bir sonucu olan sosyal medyanın yükselişi gerçek-zamanlı pazarlama kavramını teorik ve pratik olarak değiştirmiş ve günümüzde gerçek zamanlı pazarlama daha çok dikkat çekmektedir.

İnternet; geleneksel medyada devrim gerçekleştiren bir teknolojik gelişmedir. İletişimden reklamcılığa kadar birçok farklı alandaki etkisiyle bu alanları yeniden şekillendirmektedir. İnternetle birlikte insanların günlük hayattaki iletişimleri fiziksel boyuttan dijital boyuta taşınmakta ve bu değişimden birçok alan gibi reklam bilimi teorik ve pratik olarak etkilenmektedir. İnternetin ortaya çıkışı yeni medya ve sosyal mecraları ortaya çıkartmaktadır. İnsanların bu mecralar aracılığıyla iletişim kurmaları sosyalleşmeyle birlikte birçok pazarlama iletişimi pratiğini de yeni medyaya transfer etmektedir.

Yeni medya ticari ve ticari olmayan kuruluşların hedef kitleleriyle iletişimleri için önemli bir kitle iletişim aracı olmaktadır. Ticari olmayan kuruluşlar hedef kitlerini bilgilendirme amaçlı bir iletişim kurarken ticari kuruluşlar reklam ve pazarlama çalışmalarıyla hedef kitleler, mevcut ve potansiyel tüketicilerle etkileşimli bir pazarlama iletişimi pratiği gerçekleştirebilmektedir. Markalar resmi web sitelerinin yanı sıra resmi sosyal medya hesapları aracılığıyla hedef kitlelerinin nabzını tutmaya çalışmaktadır. Sosyal medyanın çift yönlü, etkileşimli, anlık yapısı ticari markaların reklam ve pazarlama iletişimi stratejilerini ve pratiklerini farklılaştırmalarını sağlayabilmektedir. Markaların gündemi takip etmeleri ve resmi sosyal medya hesapları aracılığıyla gündemdeki güncel olaylarla ilişkili reklam içerikleri üretmeleri ve hedef kitleleriyle etkileşime geçmeleri gerçek-zamanlı pazarlama pratikleri kapsamında tanımlanabilmektedir.

$\mathrm{Bu}$ çalışma real-time marketing/gerçek-zamanlı pazarlama ve sosyal medyada kullanımını araștırmaktadır. Çalıșma otomobil markalarının "Back to The Future Day/Geleceğe Dönüş Günü” olarak adlandırılan 21 Ekim 2015 tarihi Çarşamba günü sosyal medyadaki gerçek-zamanlı pazarlama pratiklerini nitel araştırma yöntemi tasarımında örnek olay tarama modeli kullanarak elde edilen verileri gösterge bilimsel analiz tekniğiyle açıklamayı amaçlamaktadır.

\section{Real-Time Marketing/Gerçek Zamanlı Pazarlama}

Geçtiğimiz son on yılda çevrimiçi reklamcılık kurumsal iletişimin en önemli unsurlardan biri olmaktadır. Geçmişte çevrimiçi reklamcılıkta genellikle statik banner reklamları kullanılmaktaydı fakat günümüzde arama motoru reklamcılığı küresel çevrimiçi reklam harcamalarının çok büyük bir kısmını kapsamaktadır. Son yıllarda çevrimiçi reklamcılığın yeni bir biçimi olan gerçek zamanlı reklamcılık, giderek artan bir şekilde kullanılmaktadır. Gerçek zamanlı reklamcılık bir açık arttırma temelinde bireysel reklam alanlarında bir web sitesindeki duyurudan sonra birkaç milisaniye içerisindeki satış olarak tanımlanmaktadır (Stange ve Funk, 2014, 305).

Gerçek-zamanlı reklamcılık temel dayanak olarak web tekniğini kullanmakta, dünün duygusuz içeriğini öldürmekte ve bağlılığı bozmaktadır. Teknolojiyi kullanan gerçek zamanlı reklamcılık "an"a odaklanarak hedef kitlenin "an"da ne 
yaptığını belirleyebilmeyi ve internet hedefli reklam envanterine dayanarak gerçek zamanlı analizleri gerçekleştirmeyi amaçlamaktadır. Gerçek zamanlı pazarlama iletişimi pratikleri, içeriğin değerini güncelleyerek reklam fiyatlarını arttıracağı öngörülmektedir (Reid, 2014, 7). Markalar internet üzerinden sosyal mecralardaki hesapları aracılığıyla ürettikleri etkileşimli içeriklerle hedef kitleleriyle interaktif bir pazarlama iletişimi gerçekleştirmenin yanı sıra gerçek zamanlı pazarlama iletişimini pratize etmektedirler.

Gerçek zamanlı pazarlama, kişiselleștirilmiş ürün ya da hizmetlerin şirketler tarafından aralıksız olarak tüketicilerin bilinçli geri bildirimleri olmaksızın değişen tüketici ihtiyaçlarını izleyerek sürekli bir şekilde kendini güncelleştirdiği bir pazarlama yaklaşımıdır. Dolayısıyla gerçek zamanlı pazarlamanın kavramsal çerçevesini pazarlamacıların ürünlerini bireysel müşterilerinin ihtiyaçlarına göre kişiselleştirmeleri hatta tüketicilerin ihtiyaçları noktasında tüketicilerin tercihleri ve ihtiyaçlarındaki değişikliklere adapte olabilecek esnekliği sürdürmeleri ve sürekli olarak bireysel müşterileri ile etkileşimi ve tüketicilerin ihtiyaçları olan ürün ya da hizmetleri satın alma sonrasında sürdürülebilir ilişkiyi sağlamak oluşturmaktadır. Böylelikle bütünleştirmesinin yanı sıra kitlelere uyarlanması ve pazarlamayla ilişkisi temalarını ayırmaktadır. Ayrıca gerçek zamanlı pazarlamada bireylerin değişen ihtiyaçları ve tercihleri ve ürün-performans ihtiyacının eşleşmesi önemlidir. Dahası bu ürün tercihi adaptasyonu bir tüketicinin ürün ve hizmet tercihleri hakkında bilgi toplanması için aktif uygulamayı gerektirmektedir (Oliver ve diğerleri, 1998, 31).

Gerçek zamanlı pazarlama ürün ve hizmet satışlarının tüketiciler ya da satış personeli kaynaklı bilgiler olmadan sürekli olarak tüketici ihtiyaçları doğrultusunda birleştirilmesi amacıyla kişiselleştirilerek (Kurian, 2013, 233) reklam mesajlarının tüketicilere bir ya da daha fazla iletişim kanalından gerçek zamanlı olarak sunulması ve bu aktivitelerin etkililiğinin izlenmesi olarak tanımlanmaktadır (Doyle, 2005, 272).

Canlı Pazarlama/Live Marketing olarak da bilinen gerçek-zamanlı pazarlama, firma personelinden ya da müşterilerden bilinçli ve kasıtlı bir araştırma faaliyeti kapsamında olmaksızın alınan girdilerle değişen müşteri ihtiyaçlarının izlenmesi ve ürün ya da hizmetlerin sürekli olarak müşteriye adaptasyonunun sağlanmasını ifade etmektedir. Müşteri ve piyasanın nabzını, nefes alışını, hararetini, kıpırtılarını izleyen bir mekanizma oluşturulabilirse ve bu mekanizma aldığı sinyallere göre müşteriler için ne yapılacağını kendi içinde, bir insan müdahalesi olmadan kararlaştırıp uygulayabilirse, Gerçek-Zamanlı Pazarlama/Real-Time Marketing ortaya çıkmaktadır. Bir canlı yayında yaşandığı gibi, kurulan sistem bir kere çalıştığında, olayların akışı içinde firma kendi kendini pazara uyarlayabilmektedir. Bunun mümkün olması için oluşturulan sistemin dışa duyarlılığı kuvvetli ve her biri düşünen, fikir üretebilen insanlardan oluşan bir entelektüel birikime sahip olması gerekir (Kaya, 2009, 265).

Bilgi teknolojileri günümüz piyasasını daha çok karmaşıklık getirmekte, ayrıca markaların gücünü yeniden inşa etmesi için bir araç haline gelebilmektedir. Yüksek hızlı iletişim, bilgisayar ağlarıve gelişmiş bilgisayar programlarıgibi mevcut kullanılan ve yeni çıkan teknolojilerle şirketler, tüketicileri ile gerçek-zamanlı diyaloglar kurmakta ve interaktif hizmetler sağlamaktadırlar. Teknolojinin kolaylaştırdığı iletişim ve hizmetler piyasa krizlerini engelleyebilmekte ve tüketicilerle bağlı ilişkiler kurmayı sağlamaktadır (McKenna, 1995, 1). 
Gerçek-zamanlı pazarlama önemli ve etkisiz yıllık plan işlemlerini elemekte ve değişikliklerle aynı düzeyde ilerlemek için planlama planlarını değiştirmektedir. Gerçek zamanlı pazarlamada planlama için kullanılan araçlar ve süreçler esnek, ortak çalışmaya dayalı ve ölçülebilir olmaktadır. Gerçek-Zamanlı Pazarlama işletme yürütme stratejilerinin sürekli geliștirilmesine yardım etmek için organizasyon üzerinde paylaşılan işletme planlarını rahatlatan bir sistem olmaktadır (Reece, 2010, 28).

McKenna $(1995,5)$ geleneksel pazarlama iletişimi pratiklerinin gerçek-zamanlı dünyada hedef kitlelerle, mevcut ve potansiyel tüketicilerle iletişim bağlamında yeteri kadar elverişli olmadığını ve tüketicilerin istek ve ihtiyaçlarını incelemek için odak grup, piyasa araştırmaları, tüketici anketleri ve diğer araçların daima sınırlı olduğunu belirtmektedir. Dolayısıyla Gerçek-Zamanlı Pazarlama bireylerin "an"ı yaşadığı günümüz dünyasında markaların sosyal mecralar aracılığıyla hedef kitleler ve tüketicilerle etkileşimli bir iletişim kurmalarıyla birlikte ihtiyaç ve istekler odağında pazarlama iletişimi faaliyetlerinin gerçekleştirilmesini sağlamaktadır.

Lieb $(2013,3)$ gerçek-zamanlı pazarlama kavramını, dışsal ve harekete geçirici olaylara anında cevap veren stratejik pazarlama iletişimi pratikleri olarak tanımlamaktadır. Tüketicilerin ilgilerini ve ihtiyaçlarını dinleyerek ya da öngörerek gerçekleştirilmektedir. Gerçek-zamanlı pazarlama iletişimi uzmanları gerçekzamanlı pazarlamanın avantajlarını şu șekilde sıralamaktadır:

1. Süpriz ve Memnuniyet: Markanın bireyle diyaloğundaki doğaçlamanın biçimine göre daha fazla bireysel etkileşimin sonucunda oluşan bireysel bir duygudur.

2. Doğru zamanda doğru mesaj: Hedef kitlelere tüketici deneyimi, daha büyük ilgi, yakınlaşma ve kişiselleștirme süresince tam zamanında devreye girerek ulaşmaktır.

3. Marka ilgisi: Marka ve son trend arasında bağlantı kurmaktır.

4. Süreklilik: Markaların her zaman yeni içerikle gerçek-zamanlı pazarlamaya katılımı sürekli olarak gerçekleştirmeleridir.

Dolayısıyla bu noktada markaların hedef kitleleri ya da tüketicileri hiç beklemedikleri anda doğal ve samimi bir dil kullanarak kuracakları doğru zamandaki iletişim mesajı doğru bir şekilde iletirken etkili olmasını sağlayacak ve gündem içerikleriyle uyumlu ya da gündem içeriklerinden üretilen reklam içerikleri markaya yönelik ilgi oluşumunu sağlayabilecektir.

Geçmişle bugünü kıyaslayarak değişen ekosistemin tamamında statik kültürden dinamik kültüre geçtiğimizin bir göstergesi bulunmaktadır. Markalar, bu kültür içinde var olabilmek için hareketli olmak zorundadır. Müşterilerin algısı, kendilerine iletilen tek yönlü mesajlara giderek kapanmaktadır. Yeni müşteri, markayı konumlandıran, markanın ürün geliştirme aşamasından, servis sonrası hizmete kadar aktif rol alan, tartışan, eleştiren, öneren ve değiştiren bir modeli temsil etmektedir. Mobilleşen hayatın dijital markaları için geriye tek bir seçenek kalmaktadır. Doğru zamanda, doğru kişiye, doğru mesajı anlık olarak iletmek, müşteriyi online mecralarda izleyerek elde edilen verileri anlık yorumlamak ve bu verilere dayalı interaktif pazarlama iletişimi gerçekleştirmek. Günümüzde dijital alanda yapılan kampanyaların çoğu gerçek zamanlı pazarlama kavramının içinde düşünülebilmektedir. Gerçek zamanlı pazarlama tekniği ile anlık değişen kullanıcı davranışını yakalayıp anında harekete geçmek bir fırsat niteliği taşımaktadır (Eskalen, 2014). 
Scott (2011, 301-311) gerçek zamanlı reklamcılığı sağlamak için gereken teknolojik alt yapının her bir bölümünün karmaşık olduğunu belirterek bu temel unsurları aşağıda sıralamıştır. Bu unsurlar;

1. Temel Teknoloji: Şirketinizle bütün bilgisayarların internet vb. ağlar aracılığıyla bilginin hızla bilgisayarlar arasında aktarılabildiği bir bağlantı ortamı. Veri ışık hızında akmaktadır.

2. Gerçek-Zamanlı Haberler Ve Yorum: Ana akım medya, analizler ve bilgi veri tabanlarını içeren dış kaynaklardan veri beslemeleridir.

3. Gerçek-Zamanlı Sosyal Web: Gerçek-zamanlı blog iletileri, tweetler, çevrimiçi video ve diğer sosyal ağ içerikleridir.

4. Gerçek-zamanlı Web Site Trafiği: Şirketin web sitesindeki bilgilerin insanların gerçek zamanda etkileşime geçtiği gibi güncellenmesidir.

5. Müşteri Veri Tabanı: Bütün mevcut müşterilerin ve onların satın alma geçmişleri, müşterilerin kurumsal iletişim bağlamında müşterilerin hangi konuda ne zaman kurdukları iletişim kayıtları.

6. Veri Tabanı Araştırmaları: Şirketin potansiyel müşterilere ve onların bilgilerine nasıl ulaşabilecekleri, satış personeli ve müşteri arasındaki iletişim durumudur.

7. Müşteri İlişkileri Yönetimi: Müşteri ilişkileri yönetimi satış ve müşteri hizmetleri temsilcilerini kullanarak mevcut müşteriler ve alıcılar ile etkileşimi yönetmek için kullandığı araçtır.

8. Web Site Analizi: Şirketin web sitesindeki etkileşimleri anlamak için kullanılan bir araçtır.

9. Sosyal Web Analizleri: İnsanların bloglarda ve diğer sosyal ağ sitelerinde ne söylediklerini izlemek için kullanılan analitik araçtır.

10. Pazarlama Otomasyonu: Alıcıları satın almaya teşvik eden eposta pazarlama ve önde gelen yöntemleri içeren araçtır.

11. Gerçek-zamanlı Taktik Tahtası: Maksimum büyüme amacıyla satın alıcıları teşvik etmek için organizasyonlar geliştirmenin en iyi yoludur.

12. Gerçek-zamanlı Performans Değerlendirme Panosu: Web temelli uygulamalar pazarlamacılar, halkla ilişkiler uzmanları, satış personeli ve üst düzey yöneticiler her gün kullanmaktadır.

13. Mobil Aplikasyonlar: Masalardan uzakta çalışan mobil uygulamalar aracılığıyla internet portalından verilerin teslim edildiği uyarı teknikleridir.

\section{Gerçek-Zamanlı Pazarlama ve Sosyal Medya}

Gerçek-zamanlı pazarlama yeni bir kavram değildir. Pazarlama iletişimi uzmanları bu kavramın tanımını ve firsatlarını oldukça uzun bir süredir bilmektedirler. Peki son zamanlarda neden bu kadar popüler olmaktadır? Sosyal medya, pazarlamanın kurallarını basit bir şekilde değiştirerek gerçek-zamanlı pazarlamayı ön plana çıkarmaktadır. Sosyal medya, markalar ve tüketicilerin birbirleriyle doğrudan iletişim kurmasını sağlayarak aradaki sinırları kaldırmaktadır. Sosyal medyada pazarlama, hedef kitlelere bir şey söylemek ya da bir mesaj yayınlamak değil hedef kitlelerle konuşmaktır. Gerçek-zamanlı pazarlama, markaların hedef kitleleriyle bir deneyimi paylaşmalarını ve konuşmanın gerçek bir parçası olmalarını sağlayarak bir adım ileriye götürmektedir. Gerçek-zamanlı pazarlama pratiklerinde cevap verme yeteneği ve sermaye dönüşümü birbiriyle bağlantılıdır. Doğru mesajın doğru hedef kitleye doğru zamanda iletilmesi önemlidir. Bir hikaye viral bir şekilde yürütülebilmekte ve bir gün içerisinde eskiyebilmektedir. Sosyal medyada pazarlama iletilerinin zamanlaması çok önemli olmaktadır (Kline, 2014, 2). 
Dünya çapında popüler bir trend ya da büyük ölçekli olaylar meydana geldiğinde bir markanın iletişim sürecine katılması ve süreci daha ileriye taşıması gerçek-zamanlı pazarlama olarak bilinmektedir. Sosyal medya mesajı diğer araçlardan daha hızlı bir şekilde iletmektedir (Olenski, 2015, 1). Bu bağlamda sosyal medya ile teorik ve pratik olarak değișen gerçek-zamanlı pazarlama, markaların pazarlama iletişimi amacıyla reklam içeriklerini ulusal ya da uluslararası gündemdeki içeriklerle uyumlu bir biçimde ilişkilendirmesini ve geleneksel medyaya göre daha hızlı olan sosyal medya aracılığıyla hedef kitleriyle gerçek-zamanlı pazarlama pratikleriyle iletebilmelerini sağlamaktadır.

Şirketler bir mesajı piyasaya iletmek istediklerinde, kampanyanın ne kadar süreceği konusunda ve çabalarının geridönüşünü görmek istediklerinde zamanlamalarını geleneksel olarak kontrol etmektedir. Ancak, sosyal medyaya daha fazla zaman ve dikkat harcandığında, markalar artık mesajları her bir sosyal platform için beklentilere uyacak şekilde uyarlamalıdır (Kerns, 2014, 6). Gerçek-zamanlı pazarlama pratikleriyle şirketler önceden yapılmış stratejik pazarlama planlarının dışına çıkarak reklam içeriklerini sosyal mecraların niteliğine göre tasarlayıp hedef kitlelerine iletebilmektedirler.

Sosyal medyaya adaptasyonun artması, reklam ve pazarlama için sosyal medya platformlarının kullanımını aniden yükseltmiştir. Tüketiciler mobil cihazların yaygın olduğu yeni bir iletişim alanında güçlenmiş ve sosyal ağlar günlük hayatları içerisindeki olayları paylaşmalarını sağlamıştır. Pazarlama iletişimi uzmanları, dijital dünyadaki hedef kitlelerle daha iyi iletişim kurmak için dijital içerikleri hızlı bir şekilde geliştirmektedirler (Fanning, 2013, 3). Mobil cihaz kullanımı ve mobil internet kullanımının da artmasıyla birlikte bireyler farklı sosyal mecralarda günlük yaşamlarını informal bir dille içerikleştirerek paylaşmakta ve dijital dünyadaki iletişimin güçlenmesini sağlamaktadırlar.

Gerçek-zamanlı pazarlamanın avantajları işletmeleri ve hedef kitleleri kapsamaktadır. Son kullanıcı bireylere kişiselleștirme, özelleştirme, sürpriz ve memnuniyet sağlamaktadır. Markalar çok büyük medya dedikodularıyla eğlenmekte, pozitif duygular oluşturarak takipçilerini arttırmaktadır (Lieb, 2013, 3). Şirketler gerçek-zamanlı pazarlama pratikleriyle stratejik pazarlama iletişimi planlarını esnetebilmekte, reklam içeriklerini gündemle ilişkilendirebilmekte, dikkat çekmekte, farkındalık oluşturabilmekte, pazarlama ve iletişim reflekslerini geliştirebilmekte, etkileşimli bir iletişim kurabilmekte ve daha çok hedef kitleye ulaşabilmektedir. Bireyler kişiselleştirilmiş reklam içerikleri alabilmekte, markanın reklam içeriklerine tepki vermesi sonucunda etkileşimli bir iletişim kurulmakta ve markaya yönelik olumlu bir tutum geliştirebilmektedir.

Sosyal medya satış tutundurma unsurlarının bir karması olması nedeniyle geleneksel bütünleşik pazarlama iletişimi araçlarının özelliklerini birleştirmektedir. Şirketler tüketicilerle konuşmaktadır. Pazarlama yöneticileri tüketicilerin birbirleriyle konuşmasının ağızdan ağıza pazarlamayı büyütmesi nedeniyle, içerikleri ve bu içeriklerin sıklığını kontrol edememektedir. Sosyal medya farklı teknolojilerin kaynağının ve medya kaynaklarının ani firsatların, gerçek zamanlı iletişim ve işitsel ve görsel sunumlar gibi çoklu medya biçimlerini ve Facebook, YouTube ve bloglar gibi birçok dağıtım platformu ile küresel erişim kapasitelerini kullanmaktadır (Mangold ve Faulds, 2009, 359). 
Sosyal medya platformlarındaki aktiviteler markalara bir insan ve kişilik yapısı sağlamakta ve onlara gerçek zamanlı etkinliklere kabul edilebilir bir şekilde tepki verme imkânı sağlamaktadır (Hakanson ve Bengtsson, 2015, 20). Bu bağlamda internet geleneksel olanı dijitalleşmeyle evirerek yeniden sunmaktadır. Internetin bir sonucu olan sosyal medya geleneksel iletişim biçimini değiştirerek dijitalleştirmiştir. Sosyal medya, birey ve bireyin, birey ve kurumun, kurum ve kurumun, kurum ve bireyin etkileșimli bir iletișim kurmasını sağlamaktadır. Ayrıca bu iletişim sürecinde formal bir kullanıldığı gibi informal bir de kullanılmakta ve bunun sonucunda bireylerle ya da tüketicilerle doğal ve samimi bir iletişim kurulmaktadır. Şirketler sosyal mecralarda marka kimliklerinin ve kişiliklerinin ötesine geçerek bir insansal kimlik ve kişilik yapısı kazanmakta ve hedef kitleler ve tüketicilerle gerçek-zamanlı pazarlama pratikleriyle iletişim kurmaktadırlar.

Reece (2010: 100) birçok insanın bir marka inşa edebilmek ve liderlik oluşturabilmek için uygulamanın bir biçimi olarak sosyal medyayı düşündügünü belirtmektedir. Farklı sosyal mecralar bu işlemi hızlandırmaktadır. Gerçek zamanlı pazarlama için sosyal medyada birkaç yöntem kullanılmaktadır. Takip edilmek için topic'lere anahtar kelimeler eklenebilmektedir. Örneğin;

- Rakipler,

- Yöneticileriniz ve şirketiniz hakkında ne söylüyorsunuz?

- İşletmenizdeki trendler,

- İșletmenizdeki ürün ve hizmetler,

- Ağınızdaki insanlardan geri bildirimler almak,

- Ağınızdaki diğerleri ile fikir alışverişi yapmak,

- Yeni kaynakları keşfetmek.

Sosyal medya, doğru yaklaşım ve yöntemler uygulandı̆̆ında iletişimi anında, kolay ve ücretsiz bir şekilde gerçekleştirebilmektedir. Twitter, hızlı değişen bilgileri ve özel teklifleri tüketicilere duyurmak için bir gerçek-zamanlı iletişim mecrası olarak kullanılmaktadır. İnsanlara ulaşmak için diğer birçok yol olmasına rağmen Twitter'ın pazarlama iletişimi uzmanları ve hedef kitleler arasında popülaritesi artmaktadır. Twitter, pazarlama iletişimi uzmanlarının kullanım kolaylı̆̆ı, hedef kitlelerin neyi ne zaman takip edeceklerini seçebilmeleri nedeniyle beğenilmektedir (Scott, 2011, 201-205).

Gerçek-zamanlı pazarlama sosyal ağların çoğunda kabul görmektedir. İnsanların günceli, akmakta olanı görmek istemesi nedeniyle gerçek zamanlı sosyal medya pazarlamacılığının kralı Twitter'dır. Twitter, gerçek zamanlı ilkeye dayanmaktadır. Görülen ileti, takip edilen en son güncellemelerden oluşmaktadır. Twitter iletileri anında görüntüleyebildiğinden gerçek-zamanlı pazarlama için tam uygun bir sosyal mecradır. Gerçek zamanlı pazarlama için Twitter kullanımının bir diğer önemli faydası organik erişim sağlamasıdır. Gerçek zamanlı pazarlamanın önemli bir kısmı viralliktir ve Twitter bu güce sahiptir. İnsanlar televizyon programlarını, canlı olayları tartışmak için Twitter'ı tercih etmektedir (O'Connor, 2015).

\section{Back To The Future/Geleceğe Dönüş Filmi ve "Back To The Future Day/Geleceğe Dönüş Günü”}

Back to The Future/Geleceğe Dönüş, Robert Zemeckis'in yönetmenlik, Bob Gale'ın yardımcı senaristlik, Steven Spielberg'in yürütücü yapımcılık yaptığı, 1985 yapımı bilim-kurgu, macera ve komedi türündeki filmdir. Başrollerinde Michael J. Fox'un 
Marty McFly, Christopher Lloyd'un Dr. Emmett Brown olarak yer aldığı filmde, Crispin Glover, Lea Thompson ve Thomas F. Wilson da yan rollerde bulunmaktadır. Geleceğe Dönüş filminde, bir Marty McFly'ın kazara 1985 yılından 1955 yılına gitmesi konu edilmektedir. McFly lisede okuyan anne ve babası ile tanışmakta ve yanlışlıkla annesinin romantik ilgisini çekmektedir. Anne ve babasının aşık olmasını engellediği için hatasını telafi edip, 1985 yılına geri dönmek zorunda kalmaktadır (https://en.wikipedia.org/wiki/Back_to_the_Future).

Geleceğe Dönüş/Back to The Future filmleri, Geleceğe Dönüş I/Back to The Future I, Geleceğe Dönüş II/Back to The Future II ve Geleceğe Dönüş III/Back to The Future III olmak üzere kurgusal olarak birbirleriyle bağlantılı olarak zaman yolcuğu temalarının bütünsel bir biçimde işlendiği bir üçleme film serisi olarak çekilmiştir. Gerçek-zamanlı pazarlama/Real-time marketing bağlamlı araştırmaya konu olan Geleceğe Dönüş Günü/Back to The Future Day 21 Ekim 2015 tarihi Geleceğe Dönüş II/Back to The Future II filminin ana temasını oluşturmaktadır.

Geleceğe Dönüş II/Back to The Future II, Bob Gale tarafından senaryosu yazılan ve Robert Zemeckis tarafından yönetilen 1989 yılı Amerikan bilim-kurgu, macera ve komedi türündeki filmidir. 1985 yılı yapımı Geleceğe Dönüş I/Back to The Future I filminden sonra Geleceğe Dönüş/Back to The Future üçlemesinin ikinci filmidir. Filmin yıldızları Michael J. Fox, Christopher Lloyd, Thomas F. Wilson ve Lea Thompson ilk film sonrasında çekilen devam filmlerinin oyuncularıdır. Marty McFly ve arkadaşı Dr. Emmet “Doc” Brown önceki zaman yolculuğu macerasında geçmişte yaptıkları hatayı düzeltmek amacıyla McFly'ın gelecekteki oğlunun tutuklanmasını engellemek için 2015'e seyahat ederler (https://en.wikipedia.org/wiki/Back_to_ the_Future_Part_II).

Dr. Emmet "Doc" Geleceğe Dönüş/Brown Back to the Future film üçlemesinde zamanda yolculuk yapabilmek için DeLorean marka DMC-12 model otomobilden bir zaman makinesi yapmıştır (https://en.wikipedia.org/wiki/DeLorean_DMC12\#Back_to_the_Future). Geleceğe Dönüş/Back to The Future film üçlemelerinde zaman makinesi DeLorean DMC-12 otomobilin kontrolü aynıdır. Sürücü zaman makinesi DeLorean DMC-12 otomobilin sürücü koltuğuna oturur ve zaman devrelerini çevirerek gidilecek zaman, şimdiki zaman ve son ayrılan zamanları, tarihleri ve saatleri gösteren çoklu bir zaman devresini aktif hale getirir. Zaman devrelerine gelecekte gidilecek zaman tarihi ay, gün, yll ve saat olarak girdikten sonra sürücü, zaman makinesi DeLorean DMC-12 otomobili saatte $88 \mathrm{mp} / \mathrm{h}, 141.6$ $\mathrm{km} / \mathrm{s}$ sürate hızlandırır ve zamanda yolculuk yapmayı sağlayan akı kapasitörünü aktif hale getirir. Otomobil hızlandıkça otomobilin etrafından çıkan beyaz ve mavi parlamalar Tesla bobinine benzer bir şekilde otomobilin etrafını çevreler ve iki dakika sonra beyaz ve mavi şimşek çakmalarıyla otomobil arkasında bir çift alevli lastik izi bırakarak ortadan kaybolur. Otomobil ayrıldığı zaman diliminden anında aynı uzaysal konumda hedeflenen zamana ulaşır ve filme göre zaman yolculuğu gerçekleştirilir (https://en.wikipedia.org/wiki/DeLorean_time_ machine). 


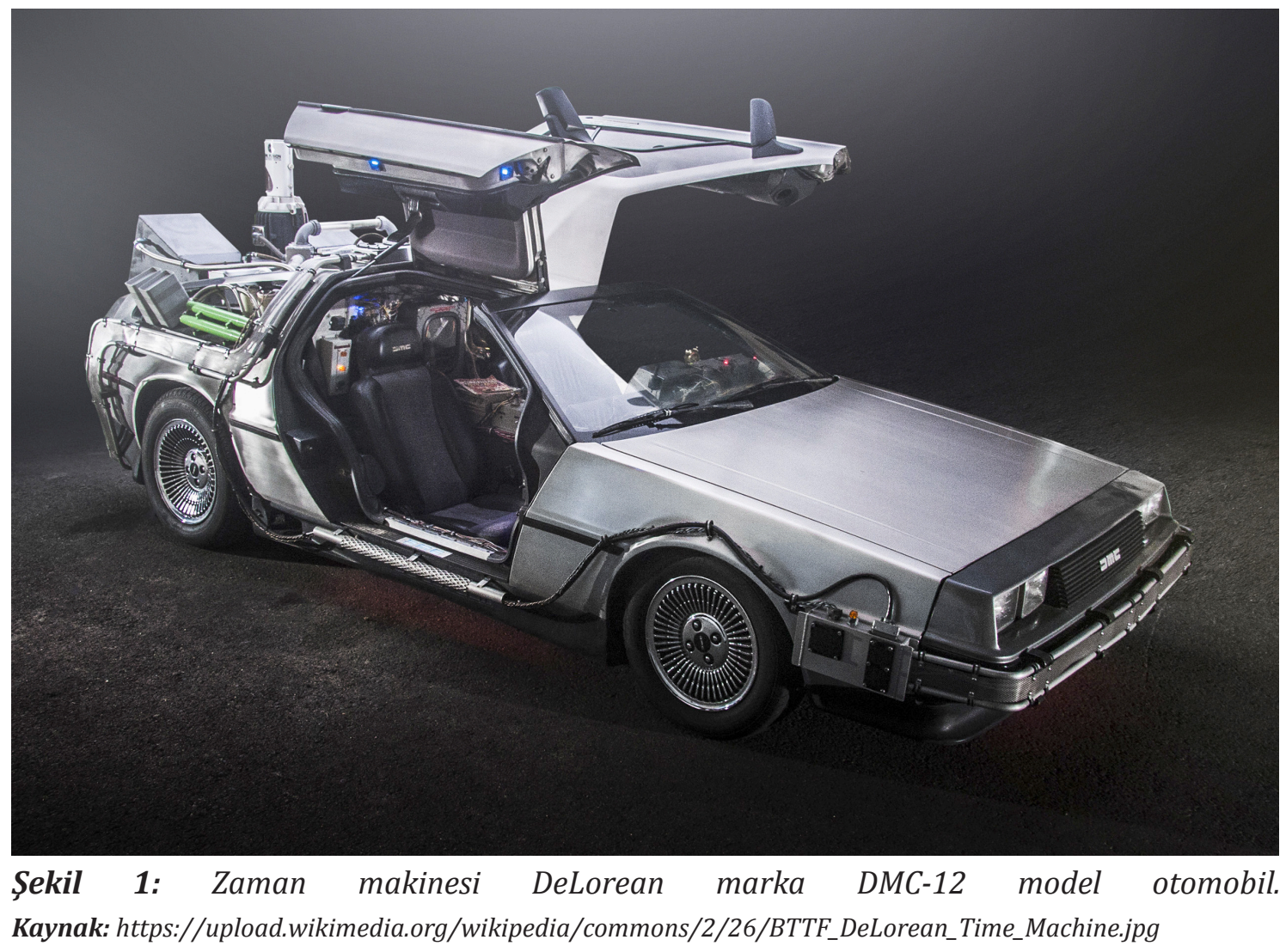

Dr. Emmet “Doc” Brown'ın geçmiş ve gelecek zamanlarda yolculuk yapmak için üzerinde modifikasyonlar yaptığı DeLorean DMC-12 otomobilin ön kokpitindeki zaman devreleri, Geleceğe Dönüş II/Back to The Future II filminin 04:45 saniyesinden 05:00 saniyesine kadar akan sahnesinde 21 Ekim 2015 tarihini göstermiştir. Geleceğe Dönüş II/Back to the Future II filminde filme konu olan 21 Ekim 2015 tarihi filmden sonra "Geleceğe Dönüş Günü"/'Back to The Future Day" olarak adlandırılmıştır. 21 Ekim 2015 “Geleceğe Dönüş Günü” geçmișten günümüze kadar geçen zaman süresince 1990'lı yıllara kadar geleneksel medyada, 2000'li yıllardan 2015 yılına kadar yeni medyada her yıl Ekim ayında medya gündemine konu olmuş ve markalar 2015 yılına kadar her 21 Ekim tarihini “Geleceğe Dönüş Günü" olarak pazarlama iletişimi amacıyla kullanmışlardır. Fakat her yıl filmin hayranları ve “Geleceğe Dönüş Günü" nün takipçileri gerçek tarihin 21 Ekim 2015 olduğunu belirtmişlerdir. Geçmişte ve gelecekte meydana gelen olayları konu edinen filmde geçmişin ve geleceğin teknolojileri ve geleceğin dünyası betimlenmeye çalışılmıştır. Filmde zaman makinesinin bir otomobil olması ve otomobillerin gelecekte hava yolunu kullanan taşıtlar olarak gösterilmesi geleceğin otomobil teknolojisinin nasıl olacağı konusunda her zaman merak oluşturmuştur. Dolayısıyla çalışma otomobil markalarının 12 Ekim 2015 'Back to the Future Day/Geleceğe Dönüş Günü'nde gerçek-zamanlı pazarlama pratiklerini nasıl gerçekleştirdikleri merakından yola çlkmaktadır. 


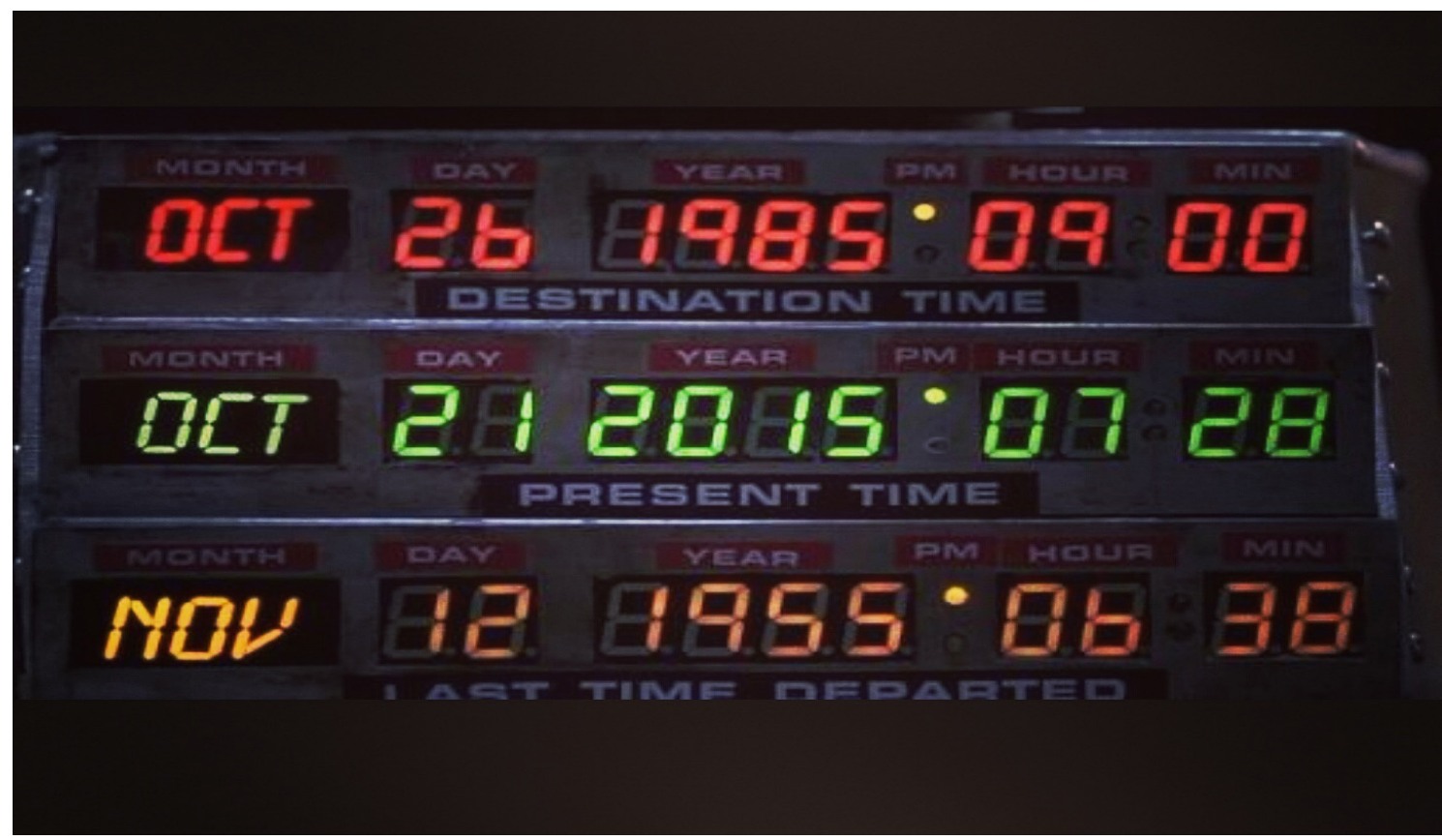

Şekil 2: Geleceğe Dönüş Günü 21 Ekim 2015.

Kaynak: https://s.instela.com/m/21-ekim-2015-dr-brown-ve-mcfly-in-1985-ten-gelmesi--i662724.jpg

\section{Yöntem}

\section{Araştırmanın Amacı ve Önemi}

$\mathrm{Bu}$ çalışma real-time marketing/gerçek-zamanlı pazarlama ve sosyal medyada kullanımını araştırmaktadır. Çalışma otomobil markalarının "Geleceğe Dönüş Günü"/ "Back to The Future Day" olarak adlandırılan 21 Ekim 2015 tarihi Çarşamba günü sosyal medyadaki gerçek-zamanlı pazarlama pratiklerini nitel araştırma yöntemi tasarımında örnek olay tarama modeli kullanarak elde edilen verileri gösterge bilimsel analiz tekniğiyle açıklamayı amaçlamaktadır.

\section{Araştırmanın Evren ve Örneklemi}

Nitel araştırma yöntemleri örneklemlerinden biri olan amaçlı örnekleme yöntemlerinden tipik durum örneklemesi kullanılmıştır. Araştırmanın evrenini otomotiv sektörü, örneklemini ise Nissan, Hyundai ve Mercedes-Benz otomobil markaları oluşturmaktadır. Çalışmada, "Geleceğe Dönüş Günü” /“Back to The Future Day" 21 Ekim 2015 tarihi Çarşamba günü Nissan, Hyundai ve Mercedes-Benz otomobil markalarının pazarlama iletişimi amacıyla sosyal medyadaki gerçekzamanlı pazarlama/real-time marketing pratikleri incelenmiştir.

\section{Araştırmanın Sınırlılıkları}

Bu çalışma teorikolarakulusalve uluslararası literatürde yapılan çalışmalarla sınırlıdır. Pratik olarak markaların sosyal medyadaki gerçek-zamanlı pazarlama iletişimi pratikleriyle sınırlıdır. Çalışma zamansal olarak 21 Ekim 2015 Çarşamba günü ve mekânsal olarak facebook, twitter ve instagram sosyal mecralarıyla sınırlandırılmıştır.

\section{Araştırma Soruları}

1. Gerçek-zamanlı pazarlama internet, yeni medya ve sosyal mecralarda pratize edilmekte midir?

2. Otomobil markaları “Geleceğe Dönüş Günü”ne özel pazarlama iletişimi pratikleri gerçekleștirmiş midir? ve nasıl bir yöntem uygulamışlardır? 
3. Otomobil markalarının “Geleceğe Dönüș Günü”nde gerçek-zamanlı pazarlama iletişimi pratikleriyle hedef kitlelerine ve rakip markalara vermek istedikleri mesaj nedir?

\section{Araştırma Verilerinin Toplanması}

$\mathrm{Bu}$ çalışmada, nitel araştırma yöntemlerinden örnek olay tarama modeli kullanılmıştır. Örnek olay tarama modelleri, evrendeki belli bir ünitenin, derinliğine ve genişliğine, kendisi ve çevresi ile olan ilişkilerini belirleyerek, o ünite hakkında bir yargıya varmayı amaçlayan tarama düzenlemeleridir. Örnek olay tarama modelleri ile yapılan araştırmalar, genel tarama modelleri ile yapılanlara oranla daha ayrıntılı ve gerçeğe yakın bilgiler verir (Karasar, 2014, s. 79-86). Örnek olay tarama modeli kullanılarak Nissan, Hyundai ve Mercedes-Benz otomobil markalarının gerçekzamanlı pazarlama/real-time marketing pratikleri gösterge bilimsel analiz tekniğiyle incelenmiştir.

Reklam üzerine yapılan çalışmalar içerisinde üzerinde en çok durulan konulardan birisi de reklamların nasıl analiz edileceği, daha doğrusu reklamların görünenin altında hedef kitlesine ne gibi mesajlar aktardığının nasıl araştırılacağıdır (Elden, Ulukök, \& Yeygel, 2005). Reklamlar bu bağlamda, tüketiciyi gittikçe daha çok yorumlaması gereken bir anlamlılık dünyasının içine çekmektedir. Tüketicinin fiziksel yaşamdaki alışılmıș yerlerinden, maddi ortamlarından koparılmış nesneler, artık şeyler değil, göstergeler oldukları posterlerin ve perdelerin üzerinde yeni simgesel anlamlar yüklenirler. Bu şekilde reklamlar, maddi dünyanın kodlanmasıyla bir bilmeceler evreni üretirler (Williamson, 2001, s. 73).

İşte bu doğrultuda, iletinin içeriğinin, yapısının ve deyiş bilimsel özelliklerinin, dilsel göstergelerinin incelemesini yapmak için göstergebilimsel çözümleme yöntemlerinden yararlanılmaktadır. Reklamlarla oluşturulan ürünlerin farklılığı çevre, değerler, simgeler, markaya bağlı oluşan imgeler tarafından oluşturulmakta ve göstergebilim bu oluşumda ön plandadır (Küçükerdoğan, 2005, s. 155).

Afiș, fotoğraf, magazin reklamları vb. gibi görsel göstergebilim alanına giren çalışmalarda, Roland Barthes'ın yaklaşımlarından söz etmek gerekmektedir. Barthes'ın görüntülerdeki anlamlandırma kuramında anahtar düşünce, anlamın düzanlam, yananlam boyutunda nasıl yayıldığıyla ilgilidir. Birinci düzlemdeki anlam boyutu olan düzanlamda, bir göstergede "kim" ya da "ne" gösterildiği belirtilirken, ikinci anlam düzlemi olarak görünenin altında görünmeyen anlamı ifade eden yananlamda ise hangi değerler, kanaatler ve fikirlerin bulunduğu tespit edilmektedir (Parsa, 2008).

\section{Otomobil Markalarının Geleceğe Dönüş Günü Sosyal Medyada Gerçek-Zamanlı Pazarlama Pratikleri}

\section{Nissan Markası}

\subsection{Zaman Devreleri Açık Reklamı \\ Reklamın Görüntüsel Anlatımı}

Çözümlemesi yapılan reklam Nissan marka GT-R model otomobilin "Geleceğe Dönüş Günü"ne özel olarak dijital manipülasyon tekniği kullanarak hazırlanan görsel reklamıdır. Görsel olarak reklam, bilgisayar desteğiyle grafik tasarım programlarında foto manipülasyon tekniği kullanılarak zaman makinesi DeLorean DMC-12 otomobile benzetilen Nissan GT-R otomobile ait üç adet görsel reklamdır. 
Metinsel olarak reklam, "Zaman devreleri açık” başlığı ve “\#OMGTR, \#GeleceğeDönüş, \#BackToTheFuture ve \#BTTFDAY” hashtaglerinden oluşmaktadır.

\section{Reklamın Gösterge Analizi}

- Gösterge: Nesne ve Kavram

- Gösteren: Nissan GT-R otomobil

- Gösterilen: Zaman makinesi

\section{Reklamın Düz Anlam ve Yan Anlam Analizi}

Reklamda düz anlam olarak süper gümüş gri Nissan GT-R otomobil gri bir alt zemin üzerinde ve arka plan önünde hareketsiz bir şekilde durmaktadır. Düz anlamın göstereni olarak Nissan GT-R otomobil düz anlamın gösterileni olarak zaman makinesini ifade etmektedir.

Yan anlam olarak süper gümüş gri zaman makinesi Nissan GT-R otomobil gri bir alt zemin üzerinde ve arka plan önünde her an zaman yolculuğuna çıkmaya hazır bir şekilde durmaktadır. Yan anlamın göstereni olarak dijtal manipülasyonla zaman makinesine benzetilen Nissan GT-R otomobil, yan anlamın gösterileni olarak filmde kullanılan zaman makinesi DeLorean DMC-12 otomobile gönderme yapmaktadır.

\subsection{Tam Zamanında Video Reklamı}

\section{Reklamın Görüntüsel Anlatımı}

Çözümlemesi yapılan reklam Nissan marka GT-R model otomobilin "Geleceğe Dönüş Günü"ne özel olarak dijital manipülasyon tekniği kullanarak hazırlanan video reklamdır. Video olarak reklam, bilgisayar desteğiyle grafik ve video işleme ve düzenleme programlarında dijital manipülasyon ve video montaj tekniği kullanılarak zaman makinesi DeLorean DMC-12 otomobile benzetilmiş Nissan GT-R otomobilin, zaman yolculuğunu gösteren altı saniyelik bir videodur. Reklam videosunda arka planda uzun bir yolda gidiși gösterilen zaman makinesi Nissan GT-R otomobil, arkasında lastiklerinden çıkmış alevleri asfaltın üzerinde bırakarak uzaklaşmakta bu esnada ön planda ise üzerinde "OMGTR" yazılı aracın plakası kendi ekseni etrafında dönmektedir.

Metinselolarakreklamiletisi, “Tamzamanında” başlığıve “\#OMGTR,\#GeleceğeDönüş, \#BackToTheFuture ve \#BTTFDAY" hashtaglerinden oluşmaktadır. "OMGTR" akroniminin “Oh My God GTR” / “Aman Allah'ım GTR” ifadesi olduğu düşünülmektedir.

\section{Reklamın Gösterge Analizi}

- Gösterge: Nesne ve Ortam

- Gösteren: Nissan GT-R otomobil

- Gösterilen: Zaman Yolculuğu

\section{Reklamın Düz Anlam ve Yan Anlam Analizi}

Reklamda düz anlam olarak süper gümüş gri Nissan GT-R otomobil düz ve asfalt bir yol üzerinde arkasında alevden şeritler bırakarak gitmektedir. Düz anlamın göstereni olarak Nissan GT-R otomobil düz anlamın gösterileni olarak yolculuğu ifade etmektedir.

Yan anlam olarak süper gümüş gri zaman makinesi Nissan GT-R otomobil düz ve asfalt bir yol üzerinde ve gün batımı arka plan önünde zaman yolculuğuna çıkmaktadır. Yan anlamın göstereni olarak dijtal manipülasyonla zaman makinesine benzetilen 
Nissan GT-R otomobil, yan anlamın gösterileni olarak filmde zamanda yolculuğa gönderme yapmaktadır.

\section{Nissan Markasının Geleceğe Dönüş Gününde Sosyal Medya Kullanımı}

Nissan resmi web sitesinde yaplan inceleme sonucunda Facebook, Instagram, YouTube, ve Twitter olmak üzere dört ayrı mecrada sosyal medyayı kullandığı görülmektedir. Nissan Türkiye, "Back to The Future Day/Geleceğe Dönüş Günü" 21 Ekim 2015 Çarşamba günü sosyal medyada hedef kitleleriyle etkileşime geçmek için görsel ve video olmak üzere iki türde hazırladığı reklamları Twitter, Facebook ve Instagram olmak üzere üç ayrı mecrada paylaşmıștır. Nissan Türkiye resmi Twitter sayfasında 3 reklam görseli 165 beğeni, 67 retweet, 3 yanıt, 1 video reklam 5 beğeni ve 3 retweet alarak toplam 243 kişiyle etkileşim gerçekleştirmiştir. Nissan Türkiye Resmi Facebook hesabında 3 reklam görseli 309 beğeni, 44 paylaşım, 7 yorum ve 1 video reklam 59 beğeni, 1 paylaşım, 2 yorum ve 4100 kez görüntülenmiştir. Nissan Türkiye Resmi Instagram hesabında 1 video reklam 50 beğeni almıștır. Nissan Türkiye Geleceğe Dönüş Günü için hazırladığı görsel ve video reklamlarla sosyal mecralarda hedef kitleleriyle toplamda 4815 kez etkileşim sağlamıştır.

Nissan Türkiye @ @issanTurkiye · 21 Eki 2015

Zaman devreleri açı.k. \#OMGTR \#GeleceğeDőnüş \#BackToTheFuture

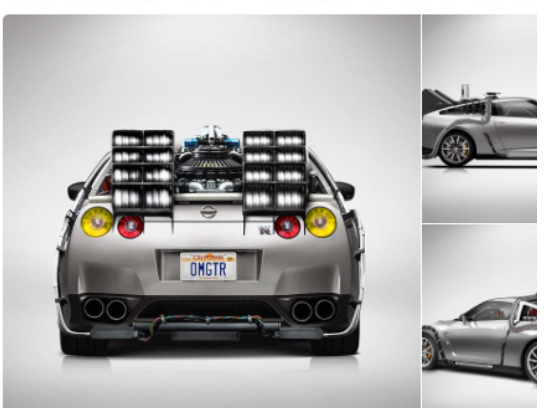

Şekil 3: Nissan Türkiye Resmi

Twitter Sayfasl

Kaynak: https://twitter.com/NissanTurkiye

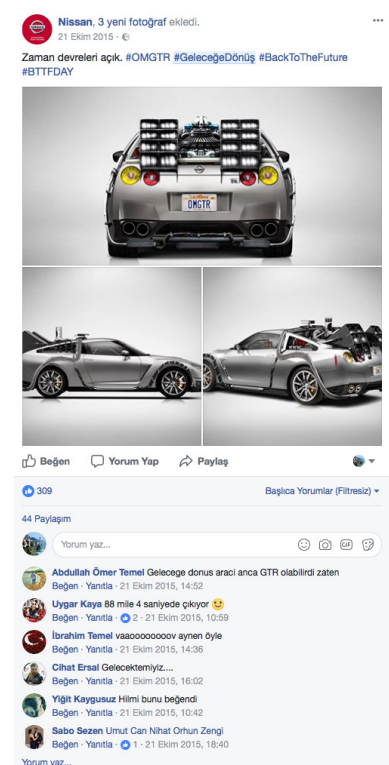

Şekil 5: Nissan Türkiye Resmi Facebook Sayfası

Kaynak: https://www.facebook.com/NissanTurkiye/ photos/pcb.1036105079773829/ $1036105026440501 /$ ?type $=3 \&$ theater

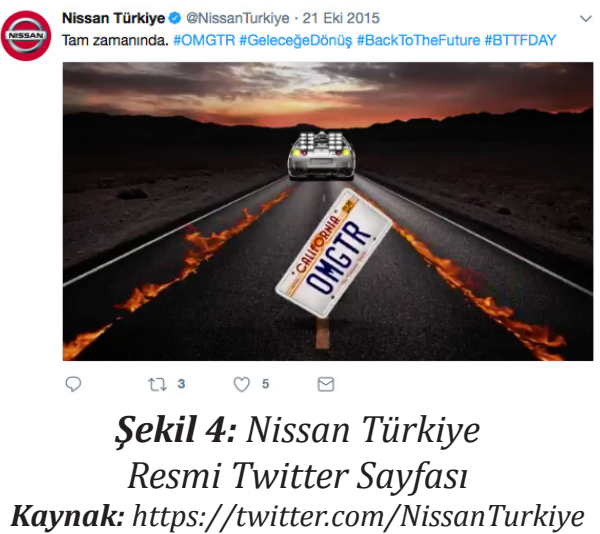

Kaynak: https://twitter.com/NissanTurkiye

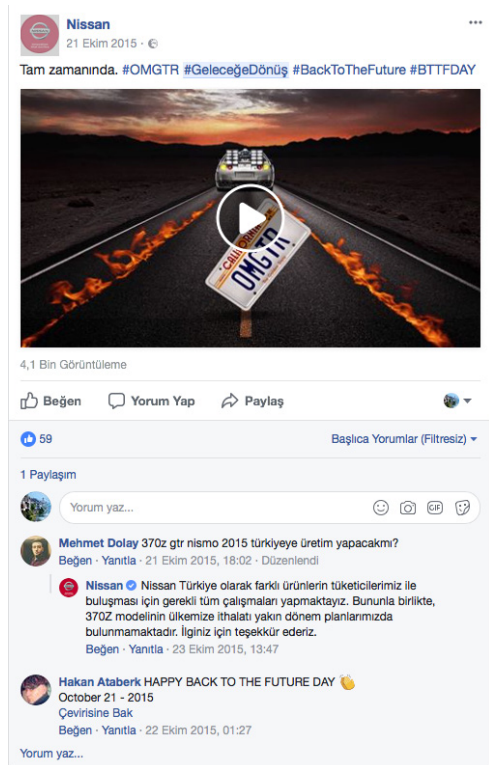

Şekil 6: Nissan Türkiye Resmi

Facebook Sayfası

Kaynak: https://www.facebook.com/ video.php?v=1036100773107593 


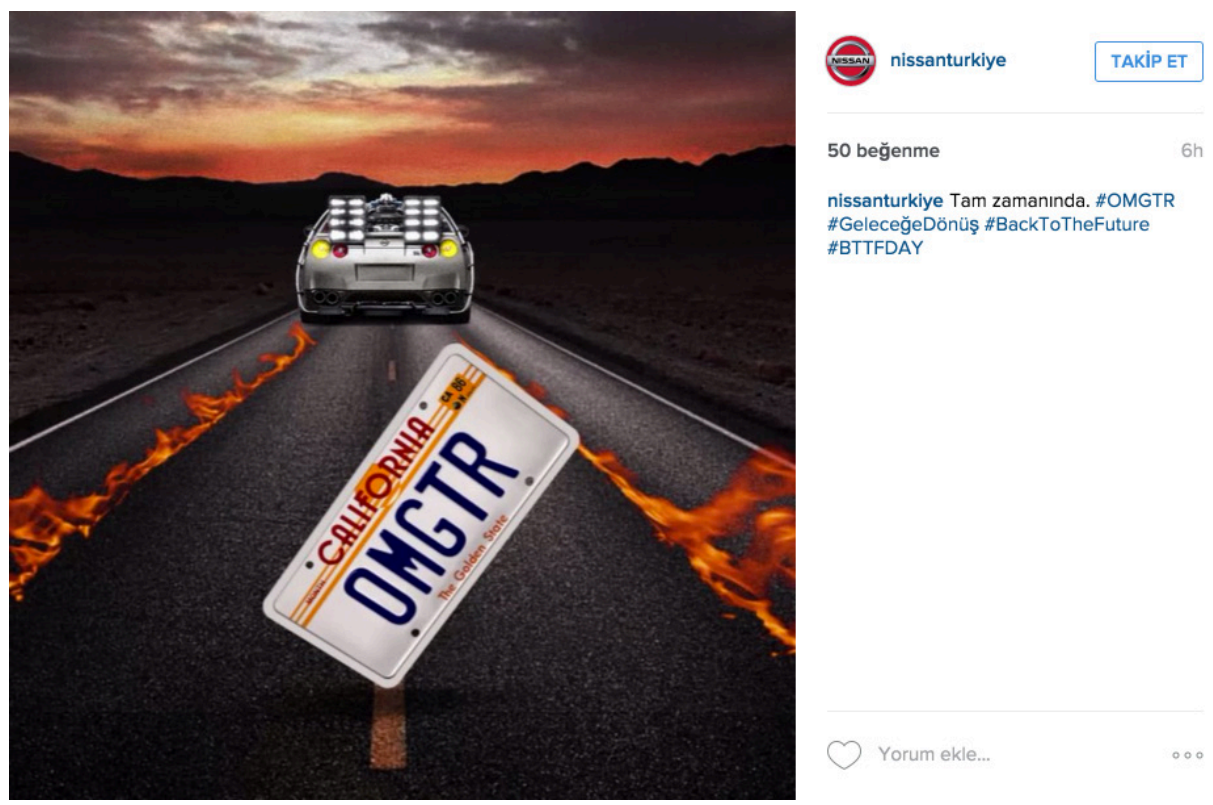

Şekil 7: Nissan Türkiye Resmi Instagram Sayfası

Kaynak: https://www.instagram.com/p/9GmiW0qeuI/?taken-by=nissanturkiye

\section{Hyundai Markası Geleceğe Dönüş Günü Reklamı}

\subsection{Yeni Tucson ile Geleceğe Yol Alın}

\section{Reklamın Görüntüsel Anlatımı}

Çözümlemesi yapılan reklam Hyundai marka Tucson model otomobilin "Geleceğe Dönüş Günü”ne özel olarak dijital manipülasyon tekniği kullanarak hazırlanan görsel reklamıdır. Görsel olarak reklam, bilgisayar desteğiyle grafik tasarım programlarında dijital manipülasyon tekniği kullanılarak zaman makinesi DeLorean DMC-12 otomobilin ön kokpitindeki zaman devreleri Hyundai Yeni Tucson modelinin ön kokpitine yerleștirilmiștir. Zaman devreleri üzerindeki tarih "Geleceğe Dönüș Günü" 21 Ekim 2015 tarihi göstermektedir.

Metinsel olarak reklam iletisi, "Yeni Tucson ile geleceğe yol alın!" başlığı ve “\#210ctober2015” ve “\#BackToTheFuture” hashtaglerinden oluşmaktadır.

\section{Reklamın Gösterge Analizi}

- Gösterge: Nesne ve Ortam

- Gösteren: Hyundai Yeni Tucson Ön Kokpiti

- Gösterilen: Zaman Yolculuğu

\section{Reklamın Düz Anlam ve Yan Anlam Analizi}

Reklamda düz anlam olarak Hyundai Yeni Tucson otomobilin ön kokpitinin camından içeri giren dairesel formdaki ışık dairenin merkezinden dıș kenarına doğru dairesel biçimlerde şiddeti sönümlenerek aydınlatmaktadır. Düz anlamın göstereni olarak Hyundai Yeni Tucson otomobil düz anlamın gösterileni olarak zamanı ifade etmektedir.

Yan anlam olarak zaman makinesi Hyundai Yeni Tucson otomobilin ön kokpitinin camından içeri giren dairesel formdaki ışık dairenin merkezinden dış kenarına doğru dairesel biçimlerde şiddeti sönümlenerek aydınlatırken zamanda yolculuğu ve uzayan ışı huzmeleri yolculuk esnasındaki hareketi ve hızı ifade etmektedir. Yan anlamın göstereni olarak dijital manipülasyonla zaman makinesine benzetilen 
Hyundai Yeni Tucson otomobil, yan anlamın gösterileni olarak zamanda yolculuğa gönderme yapmaktadır.

\section{Hyundai Markasının Geleceğe Dönüş Gününde Sosyal Medya Kullanımı}

Hyundai resmi web sitesinde yapllan inceleme sonucunda Facebook, Twitter, Instagram, Youtube, Google+ ve LinkedIn olmak üzere altı ayrı sosyal mecrada sosyal medyayı kullandığı görülmektedir. Hyundai Türkiye, "Back to The Future Day/Geleceğe Dönüş Günü” 21 Ekim 2015 Çarşamba günü sosyal medyada hedef kitleleriyle etkileşime geçmek için görsel olarak hazırladığı reklamı Facebook, Twitter, Instagram ve Google+ olmak üzere dört ayrı mecrada paylaşmıştır. Hyundai Türkiye Resmi Facebook hesabında 1 adet reklam görseli 18.540 beğeni, 290 paylaşım, 139 yorum yapılmıştır. Hyudai Türkiye Resmi Twitter sayfasında 1 adet reklam görseli 5 retweet, 13 beğeni almıştır. Hyundai Türkiye Resmi Instagram sayfasında 1 adet reklam görseli 253 beğeni almıştır. Hyundai Türkiye Resmi Google+ sayfasında 47 beğeni, 1 yorum ve 2 paylaşım almıştır. Hyundai Türkiye “Geleceğe Dönüş Günü” için hazırladığı görsel reklamla sosyal mecralarda hedef kitleleriyle toplamda $19.290 \mathrm{kez}$ etkileşim sağlamıștır.
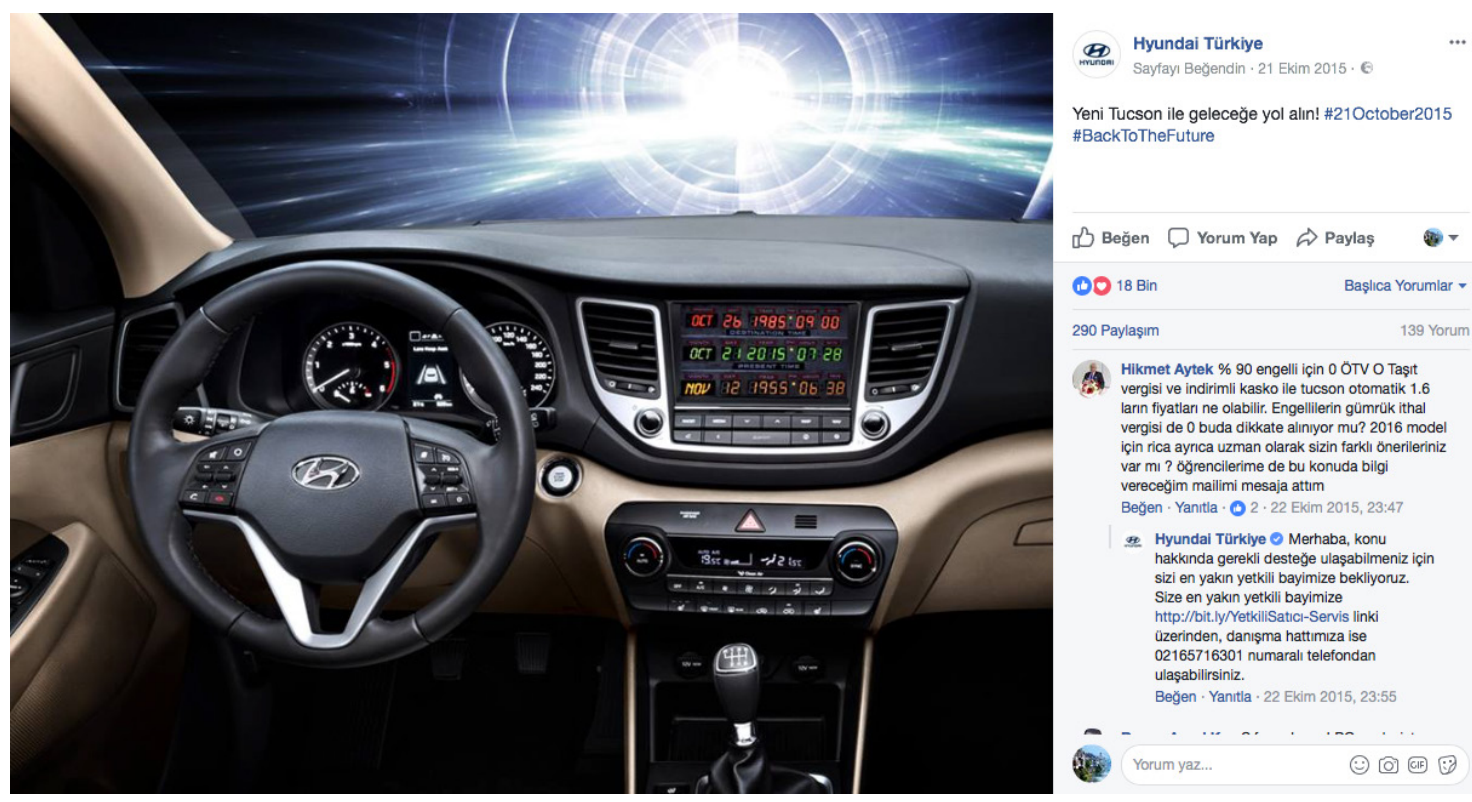

Şekil 8: Hyundai Türkiye Resmi Facebook Sayfası

Kaynak: https://www.facebook.com/HyundaiTurkiye/photos/a.1093720158184 58.23589.106366352785691/1040900959332221/?type=3\&theater 
Hyundai Türkiye @ HyundaiTurkiye · 21 Eki 2015

Mrunı̊ı Yeni Tucson ile geleceğe yol alın! \#21October2015 \#BackToTheFuture

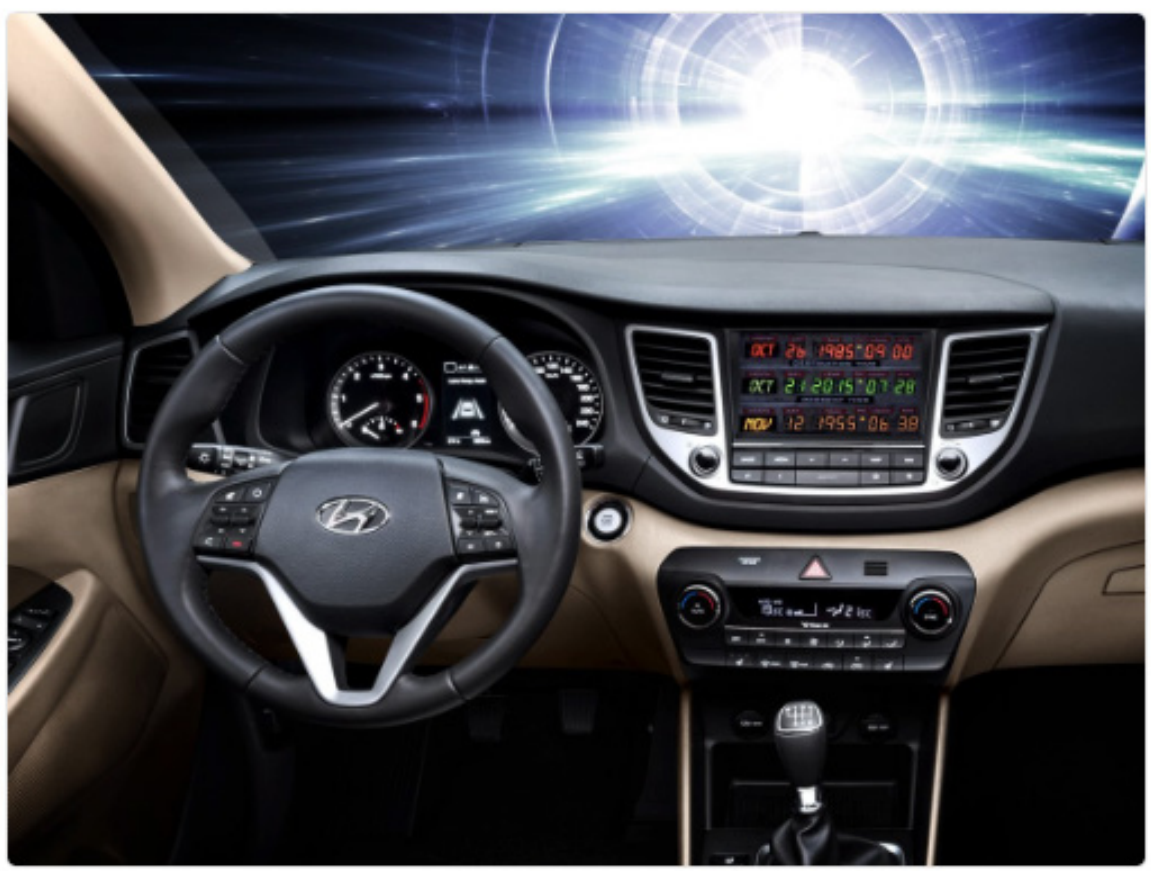
Q
〔】
( 13
$\square$

Şekil 9: Hyundai Türkiye Resmi Twitter Sayfası Kaynak: https://twitter.com/hyundaiturkiye

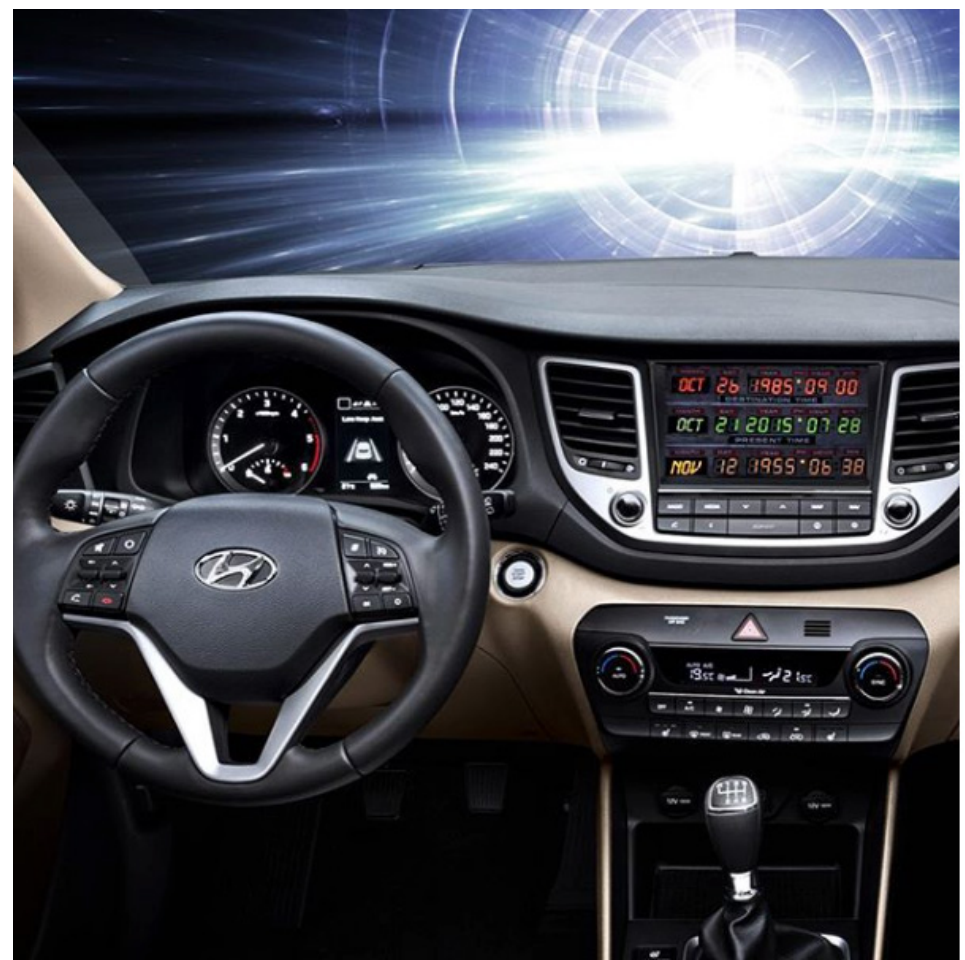

hyundaitr Yeni Tucson ile geleceğe yol alın! \#210ctober2015 \#BackToTheFuture

Şekil 10: Hyundai Türkiye Resmi Instagram Sayfası Kaynak: https://www.instagram.com/p/9F4GUqFFSY/ 


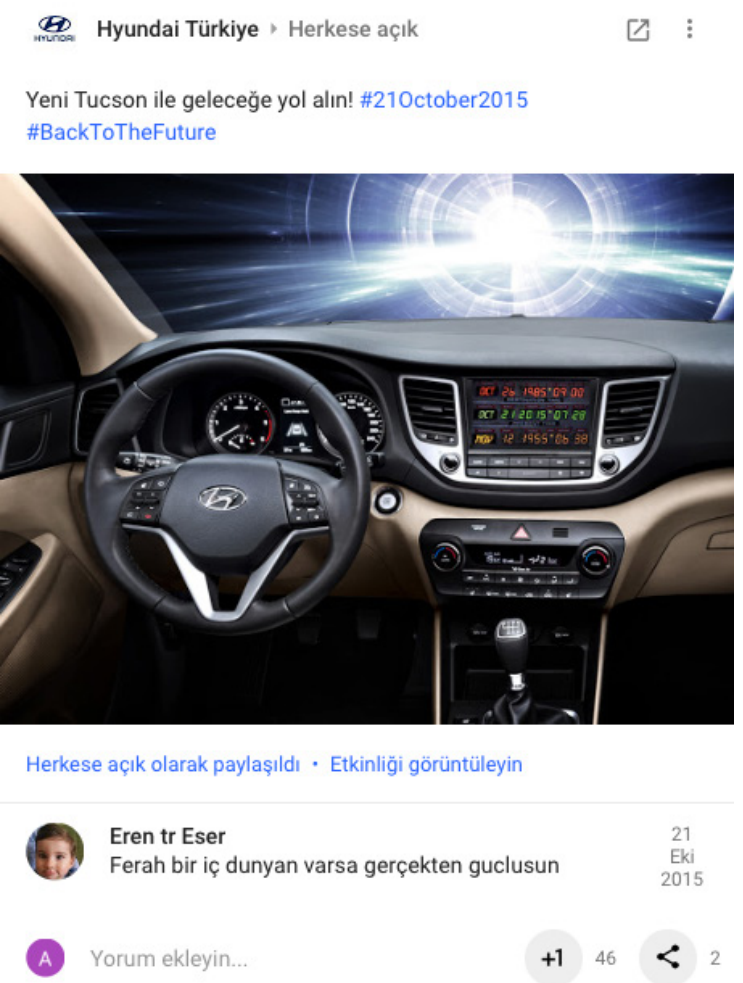

Şekil 11: Hyundai Türkiye Resmi Google+ Sayfası Kaynak: https://plus.google.com/u/0/photos/

photo/107067414331734506093/6207984548204630018?icm=false\&iso=true

\section{Mercedes-Benz Geleceğe Dönüş Günü Reklamı}

\subsection{Gelecekten Geldi}

\section{Reklamın Görüntüsel Anlatımı}

Çözümlemesi yapılan reklam Mercedes-Benz markasının "kendi kendini süren lüks sedan" olarak adlandırdığı F015 Luxury Motion konsept model otomobilin “Geleceğe Dönüş Günü”ne özel olarak hazırladı̆̆ı 16 saniyelik video reklamıdır. Reklam filmi genel planda yüksek aydınlatma direklerinin geceyi ve yolu aydınlattığı sağ aks çizgisinde kamera pan hareketi yaparken ilk olarak asfalt üzerinde beliren iki alevden şerit ilerlemektedir. Şeritlerin ilerlemelerinin bitişine doğru havada beliren ve büyüyen alev topunun patlamasıyla içinden Mercedes-Benz F015 Luxury Motion konsept otomobil elektrik kıvılcımları saçarak ortaya çıkmakta ve yol üzerinde ilerleyerek kamera açısından sağ aksta çıkmaktadır. Ani kararma geçişiyle "Mühendislerimize ilham verdiğin için teşekkürler, Doktor." ve "Geleceğe Dönüş Günü Kutlu Olsun." cümlelerinin metinleri belirerek ikinci sahneye sıçramaktadır. İkinci sahnede genel planda bir köprü üzerinde sol aks çizgisinde kamera pan hareketi yaparken Mercedes-Benz F015 Luxury Motion konsept otomobilin otonom olarak ilerlediği görülürken sol üst köşede "Gelecekten Geldi." ve "Otonom Sürüş Vizyonu." cümlelerinin metinleri belirmekte ve yavaş kararma geçişiyle Mercedes-Benz logosu parlayarak ortaya çıkmaktadır.

\section{Reklamın Gösterge Analizi}

- Gösterge: Nesne ve Ortam

- Gösteren: Mercedes-Benz F015 Luxury Motion

- Gösterilen: Zamanda Yolculuk 


\section{Reklamın Düz Anlam ve Yan Anlam Analizi}

Reklamda düz anlam olarak Mercedes-Benz F015 Luxury Motion konsept otomobil yol ve köprü üzerinde ilerlemektedir. Düz anlamın göstereni Mercedes-Benz F015 Luxury Motion konsept otomobil düz anlamın gösterileni tasarımı ifade etmektedir.

Yan anlam olarak zaman makinesi Mercedes-Benz F015 Luxury Motion konsept otomobil zamanda yolculuğu ifade etmektedir. Yan anlamın göstereni konsept olarak tasarlanan zaman makinası Mercedes-Benz F015 Luxury Motion otomobil, yan anlamın gösterileni olarak zamanda yolcuğu, geleceğin teknolojisini ve vizyonunu ifade etmektedir.

\section{Mercedes-Benz Markasının Geleceğe Dönüş Gününde Sosyal Medya Kullanımı}

Mercedes-Benz resmi web sitesinin incelemesi sonucunda Facebook, Google+, Youtube, Instagram ve Twitter olmak üzere beș ayrı sosyal mecrayı kullanmaktadır. Mercedes-Benz Türkiye "Back to The Future Day/Geleceğe Dönüş Günü" 21 Ekim 2015 Çarşamba günü için özel olarak hazırladığı reklam videosunu Facebook, Instagram, Twitter ve Google+ olmak üzere dört ayrı mecrada paylaşmıştır. Mercedes-Benz Türkiye Resmi Facebook hesabında 1 adet video reklam 3.421 beğeni, 434 paylaşım, 69 yorum ve 125.000 görüntülenmeye ulaşmıştır. MercedesBenz Türkiye Resmi Google+ sayfasında 1 adet video reklam 10 beğeni, 2 paylaşım almıştır. Mercedes-Benz Türkiye Resmi Instagram sayfasında 1 adet video reklam 1.218 beğeni, 20 yorum almıştır. Mercedes-Benz Türkiye Resmi Twitter sayfasında 1 adet video reklam 15 mesaj, 441 retweet, 594 beğeni almıştır. Mercedes-Benz Türkiye "Geleceğe Dönüş Günü" için hazırladığı video reklamla hedef kitleleriyle toplamda $128.426 \mathrm{kez}$ etkileşime geçmiștir.

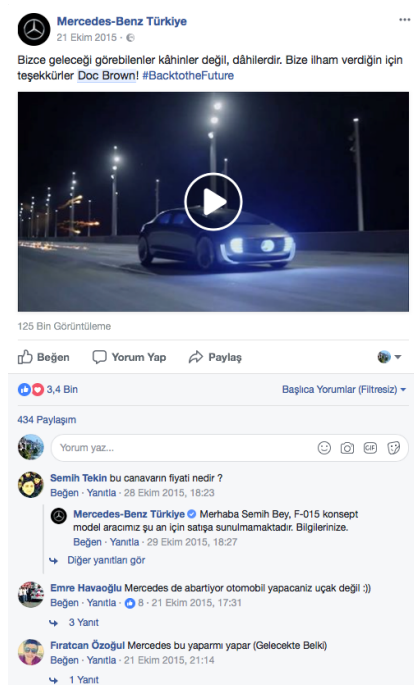

Şekil 12: Mercedes-Benz Türkiye Resmi Facebook Sayfası Kaynak: https://static.xx.fbcdn.net/ rsrc.php/v2/y4/r/-PAXP-deijE.gif

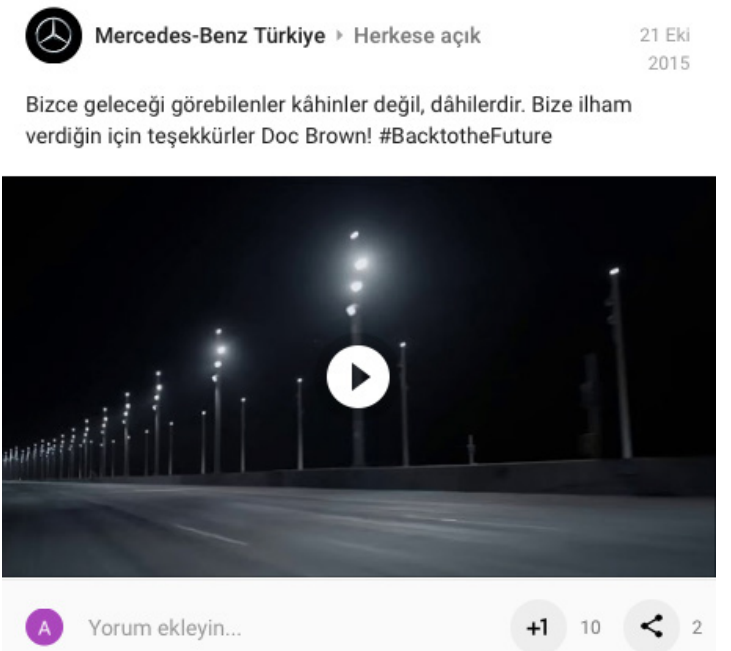

Şekil 13: Mercedes-Benz Türkiye Resmi Google+ Sayfasl Kaynak: https://plus.google.com/photos/photo/1 $16524402277814996745 / 6208007748221263666$ 

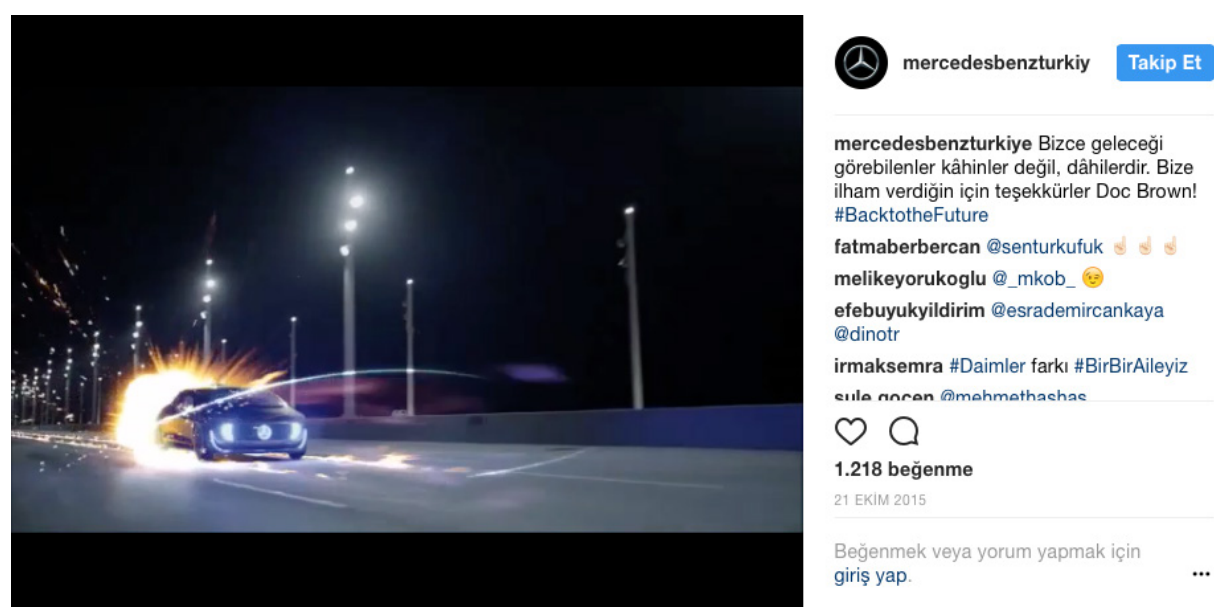

SSekil 14: Mercedes-Benz Türkiye Resmi Instagram Sayfası Kaynak: https://www.instagram.com/p/9F1rfOnjXR/?taken-by=mercedesbenzturkiye

Mercedes-Benz TR @ @MercedesTurkiye · 21 Eki 2015

Geleceği görebilenler kâhinler değil, dâhilerdir. Bize ilham verdiğin için teşekkürler Doc Brown! \#BackToTheFuture

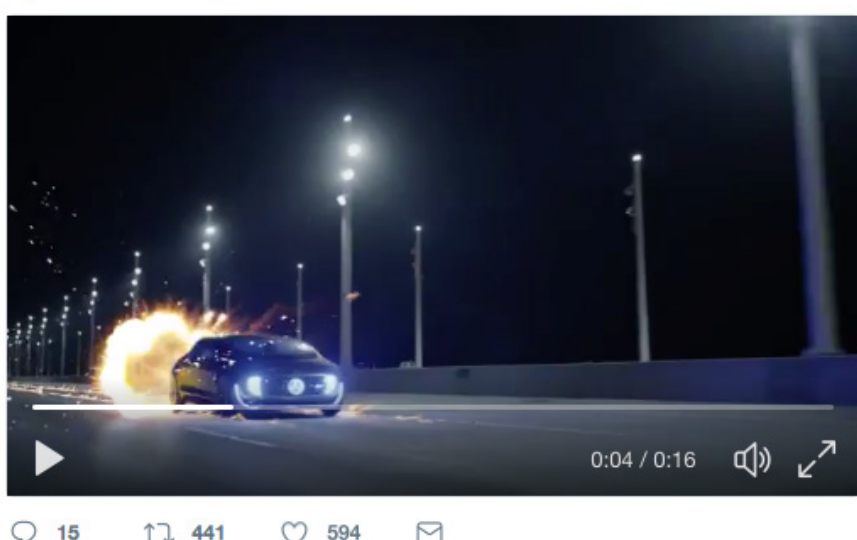

Sekil 15: Mercedes-Benz Türkiye Resmi Twitter Sayfası

Kaynak: https://twitter.com/MercedesTurkiye/status/656738049188044800

\section{Sonuç}

Gerçek-zamanlı pazarlama geleneksel bağlamda bankacılık ve telekomünikasyon sektörlerinde müşteri ilişkileri yönetiminde pratize edilmiştir. Bilgi ve iletişim teknolojilerinin gelişmesi, internetin icadı, yeni medyanın ortaya çıkması ve sosyal mecralarla devam etmesi iletişimle ilişkili birçok alanın etkilenmesine neden olmuştur. Bu etkiyle gerçek-zamanlı pazarlama kavramının teorik olarak tanımı ve pratik olarak uygulama biçimleri değișmiştir. Gerçek-zamanlı pazarlama kavramı ilk ortaya çıktığı dönemde tüketicilerin ihtiyaç ve isteklerine göre kişiselleștirilen ürünlerin pazarlanmasını ve satın alma sonrasında sürdürülebilir ilişkinin oluşturulması olarak tanımlanmaktadır. Günümüzde gerçek-zamanlı pazarlama kavramı teorik olarak şirketlerin önceden planlanan pazarlama iletişimi stratejilerini esneterek pazarlama ve reklam içeriklerini ulusal ya da uluslararası gündemlerdeki içerikle ilişkilendirerek anı yakalamaları ve hedef kitleleriyle etkileşimli bir iletişim kurmaları olarak tanımlanabilmektedir. Kavram pratik olarak internet aracılığıyla yeni medyada ve sosyal mecralarda yeni tekniklerle pratize edilmektedir.

Sosyal medya iletişimi dijitalleştirmenin yanı sıra pazarlama ve reklam içeriklerinin hedef kitlelere iletilme biçimini de değiştirmiştir. Sosyal medya bireylerin birbirleriyle 
iletişim kurmasını yanı sıra markaların hedef kitleleriyle etkileşimli bir iletişim kurmasını sağlamaktadır. Şirketler pazarlama ve reklam içeriklerini geleneksel medyaya göre daha hızlı ve etkileşimli bir şekilde internet üzerinden sosyal medya aracılığıyla hedef kitlelerine iletebilmektedirler. İnternet hizmetlerinin, mobil cihazların yaygınlaşması ve kullanıcı sayısının artması, mevcut sosyal mecralara yenilerinin eklenmesi dijital iletişimi çeşitlendirdiğigibi bireylerin günlükyaşamlarını içerikleştirerek sosyal mecralarda paylaşmaları dijital iletişimi güçlendirmektedir.

Şirketlerin pazarlama iletişim pratikleri dijital bir dönüşüm yaşamaktadır. Yasal olarak belirtilen şartlarda her şirketin web sayfasının bulunması zorunlu tutulmaktadır. Sosyal medya konusunda yasal bir yaptırım olmamasına rağmen şirketler sosyal mecralarda açtıkları hesaplar aracılığıyla hedef kitlelerle iletişime geçmektedirler. Çalışma araştırmaya konu olan Geleceğe Dönüş filmi ve 21 Ekim 2015 “Geleceğe Dönüş Günü” nde otomobil markalarının sosyal medyayı pazarlama iletişimi amacıyla nasıl kullandıkları sorusundan merakla yapılmıştır.

Araştırmanın örnekleminde bulunan Nissan, Hyundai ve Mercedes-Benz markalarının “Geleceğe Dönüş Günü” gerçek-zamanlı pazarlama pratiklerinin örnek olayları incelendiğinde üç markanın bugüne özel pazarlama iletişimi gerçekleştirdikleri görülmektedir.

Nissan markasının “Geleceğe Dönüş Günü” için hazırladığı görsel reklam Zaman Devreleri Açık ve video reklam Tam Zamanında reklamlarında Nissan GT-R model otomobil düz anlamın göstereni olarak Nissan GT-R otomobili ve düz anlamın gösterileni olarak zaman makinasını ifade ederken yan anlamın göstereni olarak zaman makinesi Nissan GT-R otomobili, yan anlamın gösterileni olarak zaman makinesi DeLorean DMC-12 otomobile gönderme yapmaktadır. Her iki reklamda düz anlam olarak yolculuğu ifade ederken yan anlam olarak zamanda yolculuğa gönderme yapmaktadır. Nissan marka GT-R model otomobilin rengi süper gümüş gridir. Otomobilin hatlarını en güzel yansıtan renkler arasında yer alan gri rengin, güç sembolü olarak kabul edilmesi nedeniyle Nissan markasının GT-R modelini tasarımı, teknolojisi, gücü, hızı, teknik özellikleriyle zamanının ötesinde bir otomobil olarak konumlandırması nedeniyle diğer otomobil markalarına saygı duymaları gerektiği mesajı vermektedir. Zaman makinesi Nissan GT-R otomobilin gelecekten gelmesi Nissan markasının gelecekte ikon bir marka olarak var olacağını belirtmektedir.

Hyundai markasının “Geleceğe Dönüş Günü” için hazırladığı Yeni Tucson ile Geleceğe Yol Alın görsel reklamında düz anlamın göstereni olarak Hyundai Yeni Tucson otomobil ve düz anlamın gösterileni olarak zaman ifade edilirken yan anlamın göstereni olarak zaman makinesi Hyundai Yeni Tucson otomobil ve yan anlamın gösterileni olarak zamanda yolculuğa gönderme yapılmaktadır. Hyundai marka Yeni Tucson model otomobilin ön kokpitinin camından içeri giren $1 s ̧ ı k$, geleceği, teknolojiyi simgelemektedir. Reklam görselinde otomobilin sürücü koltuğunun boş olması reklamı gören bireyin kendisini otomobilin içinde hissetme algısı, denemek, dokunmak ve sürmek isteği oluşturulmaktadır. Zaman makinesi Hyundai Yeni Tucson otomobilin gelecek zamana yolculuk yapması Hyundai markasının gelecekte teknolojik bir marka olarak var olacağını belirtmektedir.

Mercedes-Benz markasının "Geleceğe Dönüş Günü” için hazırladığı Gelecekten Geldi reklamında düz anlamın göstereni olarak Mercedes-Benz F015 Luxury Motion konsept otomobili ve düz anlamın gösterileni olarak tasarımı ifade ederken yan 
anlamın göstereni olarak konsept olarak tasarlanan zaman makinası Mercedes-Benz F015 Luxury Motion otomobil, yan anlamın gösterileni olarak zamanda yolcuğu, geleceğin teknolojisini ve vizyonunu ifade etmektedir.

Mercedes-Benz marka F015 Luxury Motion konsept model otomobilin zamanda yolculuğuyla gelecekten gelişi ve geleceğin teknolojisini günümüze getirişi fütüristtik bir algı oluşturmaktadır. Otomobilin tasarımı, hatları ve çizgileri gizemli ve mistik bir algı oluşturmaktadır. Otomobilin çelik grisi rengi, reklam iletisinin dikkat çekici bir unsur olurken Geleceğe Dönüş Film serisindeki zaman makinesi DeLorean DMC12 otomobilin dış karoserinin çelik ve renginin gri olmasıyla ilişkisellik ve benzerlik sağlamaktadır. Otomotiv literatüründe gri renk güç, otorite ve saygınlık sembolü olarak kabul edilmekte markanın imajını güçlendirmektedir. Otomobilin beyaz ve mavi renk led aydınlatmaları sofistikeliği ve teknolojiyi çağrıştırmaktadır.

Günümüzde zamanda yolculuk yapılabilir mi? sorusu üzerinde tartışmalar yapılırken bir otomobilin zaman makinesi olabileceği düşüncesi heyecan verebilmektedir. Günümüz gerçekliğinde zaman makinesi bir otomobil metaforik olarak geleceğin dünyasını ve otomobillerin geleceğini temsil etmektedir. Türkiye'de otomotiv sektöründe faaliyet gösteren 47 otomobil markasından Nissan, Hyundai ve MercedesBenz markaları "Geleceğe Dönüş Günü” nde gerçek-zamanlı pazarlama iletişimi pratikleriyle hedef kitlelerine ve diğer markalara otomotiv teknolojisi olarak üstün oldukları ve gelecekte de ikon markalar olarak var olacakları mesajı vermekte ve günümüzdeki marka imajlarını güçlendirmektedirler.

\section{Kaynakça}

Doyle, S. (2005). Software Review. Real-Time Technologies in Marketing-Interaction Management. Database Marketing \& Customer Strategy Management.

Elden, M., Ulukök, Ö., \& Yeygel, S. (2005). Şimdi Reklamlar. İstanbul: İletişim Yayınları.

Eskalen,S.(2014,0119).http://www.serkaneskalen.com/gercek-zamanli-pazarlamaetkisi/. 01 07, 2015 tarihinde http://www.serkaneskalen.com/: http://www. serkaneskalen.com/gercek-zamanli-pazarlama-etkisi/ adresinden alındı

Fanning, B. (2013). Case Study: Oreo's Agile Use of Real-time Social Media Marketing During Super Bowl XLVII's Power Outage.

Hakanson, D., \& Bengtsson, T. (2015). Real-Time Marketing Effects on Brands in Social Media. Halmstad University, International Marketing Program. Sweden: Halmstad University.

Küçükerdoğan, R. (2005). Reklam Söylemi. İstanbul: Es Yayınları.

Karasar, N. (2014). Bilimsel Araştırma Yöntemi. Ankara: Nobey Yayın Dağıtım.

Kaya, İ. (2009). Müşterinize Dokunmanın 375 Yolu, Pazarlama Bi'Tanedir! (Bir Pazarlamalar Ansiklopedisi). İstanbul: IV. Dijital Baskı.

Kerns, C. (2014). Trendology - Building an Advantage Through Data-Driven Real-Time Marketing. USA, New York: palgrave macmilan.

Kline, A. M. (2014, 09 07). Real-Time Marketing: Go Beyond The Buzz.

Kurian, G. T. (2013). The AMA. Dictionary of Business and Management. The AMA. Dictionary of Business and Management. 
Lieb, R. (2013, 12 17). A Market Definition Report. Real-Time Marketing: The Agility Leverage 'Now'.

Mangold, W. G., \& Faulds, D. (2009). Social Media:The New Hybrid Element of The Promotion Mix. Business Horizons.

McKenna, R. (1995). Real-Time Marketing. Harvard Business Review.

O’Connor, P. (2015, Ağustos 5). https://socialmediaweek.org/blog. Kasım 20, 2017 tarihinde https://socialmediaweek.org: https://socialmediaweek.org/ blog/2015/08/real-time-marketing/ adresinden alındı

Olenski, S. (2015, 11 20). http://www.forbes.com/sites/steveolenski/2015/11/20/ real-time-marketing-for-social-media-integrating-large-scale-events/. 1 11, 2016 tarihinde http://www.forbes.com: http://www.forbes.com/ sites/steveolenski/2015/11/20/real-time-marketing-for-social-mediaintegrating-large-scale-events / adresinden alındı

Oliver, R. W., Rust, R. T., \& Varki, S. (1998). Real-Time Marketing. Marketing Management.

Parsa, S. (2008). Film Çözümlemeleri. İstanbul: Multilingual Yabancı Dil Yayınları.

Reece, M. (2010). Real-Time Marketing for Business Growth. New Jersey: Pearson Education.

Reid, C. (2014). Real-Time Marketing Can Keep Businesses Successful-But How? Econtentmag.

Scott, D. M. (2011). Real-Time Marketing \& PR. New Jersey: John Wiley \& Sons.

Stange, M., \& Funk, B. (2014). Real-Time Advertising. Business \& Information Systems Engineering.

Williamson, J. (2001). Reklamların Dili:"Reklamlarda Anlam ve Ídeoloji". Ankara: Ütopya Yayınları.

\section{İnternet}

https://en.wikipedia.org/wiki/Back_to_the_Future Erişim Tarihi: 30.11.2017

https://en.wikipedia.org/wiki/Back_to_the_Future_Part_II Erişim Tarihi: 30.11.2017

https://en.wikipedia.org/wiki/DeLorean_DMC-12\#Back_to_the_Future Erişim Tarihi: 30.11.2017

https://en.wikipedia.org/wiki/DeLorean_time_machine Erişim Tarihi: 30.11.2017

http://www.taylormadecanada.com/resources/files/197_Real_Time_Marketing_ Design_ex4.pdf Erişim Tarihi: 30.11.2017

http://rebeccalieb.com/sites/default/files/downloads/1312\%20RealTime\%20 Marketing\%20RL.pdf Erişim Tarihi: 14.11.2017

\section{Şekiller}

Şekil 1: Zaman makinesi DeLorean marka DMC-12 model otomobil.

Kaynak:https://upload.wikimedia.org/wikipedia/commons/2/26/BTTF_

DeLorean_Time_Machine.jpg Erişim Tarihi: 13.12.2017 
Şekil 2: 21 Ekim 2015 Geleceğe Dönüş Günü.

Kaynak:https://s.instela.com/m/21-ekim-2015-dr-brown-ve-mcfly-in1985-ten-gelmesi--i662724.jpg Erişim Tarihi: 30.11.2017

Şekil 3: Nissan Türkiye Resmi Twitter Sayfası Kaynak: https://twitter.com/NissanTurkiye Erişim Tarihi: 30.11.2017

Şekil 4: Nissan Türkiye Resmi Twitter Sayfası

Kaynak: https://twitter.com/NissanTurkiye Erişim Tarihi: 30.11.2017

Şekil 5: Nissan Türkiye Resmi Facebook Sayfası

Kaynak:https://www.facebook.com/NissanTurkiye/photos/ pcb.1036105079773829/1036105026440501/?type=3\&theater Erişim Tarihi: 30.11.2017

Şekil 6: Nissan Türkiye Facebook Resmi Sayfası

Kaynak: https://www.facebook.com/video.php?v=1036100773107593

Erişim Tarihi: 30.11.2017

Şekil 7: Nissan Türkiye Resmi Instagram Sayfası

Kaynak: https://www.instagram.com/p/9GmiW0qeuI/?takenby=nissanturkiye Erişim Tarihi: 30.11.2017

Şekil 8: Hyundai Türkiye Resmi Facebook Sayfası

Kaynak:https://www.facebook.com/HyundaiTurkiye/photos/a.109372015 818458.23589.106366352785691/1040900959332221/?type=3\&theater Erişim Tarihi: 30.11.2017

Şekil 9: Hyundai Türkiye Resmi Twitter Sayfası

Kaynak: https://twitter.com/hyundaiturkiye Erişim Tarihi: 30.11.2017

Şekil 10: Hyundai Türkiye Resmi Instagram Sayfası

Kaynak: https://www.instagram.com/p/9F4GUqFFSY/ Erişim Tarihi: 30.11.2017

Şekil 11: Mercedes-Benz Türkiye Resmi Google+ Sayfası

Kaynak:https://plus.google.com/u/0/photos/ photo/107067414331734506093/6207984548204630018?icm=false \&iso=true Erişim Tarihi: 30.11 .2017

Şekil 12: Mercedes-Benz Türkiye Facebook Resmi Sayfası

Kaynak:https://static.xx.fbcdn.net/rsrc.php/v2/y4/r/-PAXP-deijE.gif Erişim Tarihi: 30.11.2017

Şekil 13: Mercedes-Benz Türkiye Google+ Resmi Sayfası

Kaynak:https://plus.google.com/photos/

photo/116524402277814996745/6208007748221263666 Erişim

Tarihi: 30.11.2017

Şekil 14: Mercedes-Benz Türkiye Instagram Resmi Sayfası

Kaynak:https://www.instagram.com/p/9F1rfOnjXR/?taken-

by=mercedesbenzturkiye Erişim Tarihi: 30.11.2017

Şekil 15: Mercedes-Benz Türkiye Twitter Resmi Sayfası

Kaynak: https://twitter.com/MercedesTurkiye/

status/656738049188044800 Erişim Tarihi: 30.11.2017 